\title{
Natural Resources Endowment and WTO
}

\author{
Louai SOUKAR ${ }^{1+}$ \\ ${ }^{1}$ University of Bordeaux, France, Laboratoire d'Analyse et de Recherche en Economie et Finances Internationales \\ (Larefi), France
}

\begin{abstract}
The objective of the study is to investigate the asymmetric impact of the World Trade Organization (WTO) across developing countries. We also demonstrate the lack of homogeneity between these countries in terms of their market growth and their dependence on natural resources. Empirically, we classified our sample of countries into categories using cluster analysis, and we relied on the gravity models to estimate the effects of WTO. We found that emerging resource-rich countries most significantly benefit from their accession to the organization. However, regional integration and bilateral agreements benefit non-emerging resource-rich countries. Although resource-poor countries have received uneven benefits from WTO accession, non-emerging resource-poor countries have benefited more from accession. However, regional integration is an appropriate trade strategy for both resource-poor categories, and generalized system of preferences (GSP) benefit the non-emerging markets. Finally, accession to WTO does not increase trade in natural resources for any specific category of countries discussed in this study.
\end{abstract}

Keywords: WTO, Natural resources, Gravity model

JEL Classifications: F13, F15

Received 27 June 2019, Accepted 14 August 2019

\section{Introduction}

Natural resources endowment and its effects on general economic aspects are crucial issues from academic and political perspectives. They are indispensable inputs for production and crucial for maintaining a high standard of living. In recent years, the share of natural resources in world trade has increased from 15 percent to about 30 percent in the total world trade between 1995 and 2015.1) The importance of natural resources in international trade and their role in the economic growth and development process of many economies depends on several geographical and economic dimensions. First, natural resources are unevenly distributed among countries. They are concentrated in a small number of countries, while others have limited domestic supplies. This disparity leads to profitable trading opportunities among countries. Second, one important implication for the uneven distribution of natural resources among nations is 
the dominant position of the natural resources sector in many countries. Many natural resource producers depend totally on resource exports, which tend to be highly concentrated in a few products. Besides this, trade can encourage over-specialization in resource extraction. Hence, this endowment of natural resources increases the contribution of the mining and agriculture sectors to the gross domestic product (GDP) in these countries. ${ }^{2}$ ) Third, natural resources provide a variety of products. We can distinguish between three main categories of natural resourcesagricultural raw materials, minerals, and fuel.3) Fourth, the fluctuation of prices in the global market is one of the most important characteristics of natural resources commodities when compared to other goods. This fluctuation of prices is a source of uncertainty that adversely affects investment and production decisions. Additionally, volatility in the price of natural resources has long been considered a problem for countries heavily reliant on commodity exports. The last characteristic of natural resource goods is the low applied tariff; in the natural resource sectors, this tariff is generally lower than total products and than manufacturing and food sectors.

These economic and geographical features of natural resources, especially their uneven distribution across economies, affect the potential gains from the regulation of international trade. There are two forms of international trade regulation-one is a multilateral trade agreement ruled by the World Trade Organization (WTO), and the other comprises bilateral or plurilateral regional trade agreements (RTA). This study will discuss the linkages between the abundance of natural resources and the WTO.

The WTO, since its inception in 1995, and its predecessor, the General Agreement on Tariffs and Trade (GATT), have enhanced trading systems and promoted global trade.4) The WTO states that "The WTO is the only international organization dealing with the global rules of trade between nations." Further, it states that its "...overriding objective is to help trade flow smoothly, freely, fairly, and predictably."5) The WTO has 164 members, representing about $98 \%$ of the international trade. Additionally, it has two main objectives. First, it aims to promote international trade by removing the tariff barriers imposed between countries. Second, it engages in the resolution of trade disputes between member countries. However, the impact of the WTO on international trade is a question that is not yet settled at the academic level. Some studies found that the accession to WTO does not promote international trade between countries. Thus,

1) Source: United Nations Conference on Trade and Development (UNCTAD) database

2) From sample of 200 countries over the period (1995 2015), there are about 80 countries that their share of natural resource in total exports is more than 40 percent, about 70 countries that their concentration index is more than 0.40 and about 40 countries that the contribution of mining and agriculture in GDP is more than 20 percent, see Appendix 1.

3) See Fouquin and et al. (2006) to review the several rationales for this distinction.

4) Henceforth we use GATT/WTO as a synonym for expressing the impact of both the General Agreement on Tariff and Trade (GATT) and World Trade Organization (WTO), while WTO as a synonym for the impact of World Trade Organization (WTO).

5) Taken from Taken from the official site of WTO. 
there are other factors that determine global trade flows between nations. However, other studies proved that the WTO promoted trade between member nations. Academic studies have also raised the question of the asymmetry in the impact of the WTO on developed and developing countries. There is also no unified view on this subject; some studies have found that developed countries benefit more from WTO accession than developing countries, while others have found the opposite.

However, the International Monetary Fund (IMF) classified 34 countries as developed economies, and the rest as developing countries.6) This shows the dissimilarity between member countries in terms of their development level. Besides, the IMF classified some developing countries as emerging markets. This implies that they are not homogeneous in terms of market growth; while some developing countries are characterized by emerging markets, others are not. As stated earlier, one of the main economic and geographical features of natural resources is their unequal distribution among nations, particularly among developing countries. Therefore, these countries are heterogeneous in terms of their economic structures, and they depend on their natural resource endowment. This presupposes that certain developing countries are rich in natural resources, while others are poor.

The share of developing countries in international trade has increased in the recent decades. Furthermore, these countries aim accession to the WTO in order to increase their gains from international trade. Nevertheless, this heterogeneity between developing countries, in terms of economic structures, makes the gains from the accession to the WTO a debatable issue. Based on the literature, our interest is to continue the research on the effects of WTO on developing countries, within the framework of natural resource endowment. Therefore, we hypothesize the existence of potential asymmetric effects of WTO across resource-rich and resource-poor developing countries.

In this study, we empirically examine the impact of the WTO on member countries, especially developing countries, in the context of their natural resource endowment. However, developing countries are not homogenous in terms of their economic structures, and they depend on their natural resource endowment and market growth. We follow a two-step procedure of analysis. First, we classify our sample of countries, using cluster analysis and IMF classification, into the following five categories; advanced countries, emerging natural resource-rich countries, non-emerging natural resource-rich countries, emerging natural resource-poor countries, and non-emerging natural resource-poor countries. Second, we rely on the gravity model as an analysis tool, using dummy variables for each category, to quantify if asymmetric gains arise from the accession of developing countries to the WTO. By measuring the effects of GATT/WTO's membership on trade flows, the literature has remarkably produced diverse results. Meanwhile, it principally focused on the asymmetric effect of GATT/WTO between industrialized

6) International Monetary Fund. (2015). World Economic Outlook: Adjusting to Lower Commodity Prices. Washington 
and developing countries. Therefore, the main contribution of this study is to investigate the potential asymmetric effect of the WTO across developing countries, particularly between resource-rich countries and resource-poor countries. Therefore, this study extends the literature by studying the effects of the WTO on member countries.

We can present our main results. With respect to natural resource-rich countries, our estimation shows that the WTO exerts a positive impact on resource-rich countries having emerging markets and diversified export structures, while regional integration and bilateral agreements do not influence an increase in a country's exports toward its partners countries. This reflects that emerging resource-rich countries are more inclined toward full trade liberalization and exports to global markets. This is mainly due to their export diversification policies and an improvement in their competitiveness. Furthermore, our findings show that WTO does not contribute toward increasing the exports of non-emerging resource-rich countries. These countries heavily depend on exporting natural resources and their export structures are not diversified enough. On the one hand, regional integration and bilateral agreements stimulate their non-resource exports. This reveals that non-emerging resource-rich countries are more oriented toward regional markets because of their lack of competitiveness. On the other hand, the impact of WTO is positive across resource-poor countries. Both emerging resource-poor and non-emerging resource-poor countries have received uneven benefits from their accession to the WTO. Results indicated that emerging markets benefited less from the accession. Since they have been adopting trade liberalization policies that essentially rely on exports, accession to the WTO has not affected their trade patterns. With regards to regional integrations, we also note that they have a slightly more positive effect on both categories when compared to WTO's impact. This reveals the importance of establishing trade blocks for resource-poor countries. Bilateral agreements have also contributed toward increasing exports of both resource-poor categories, but to a lesser extent. The results also showed that only non-emerging resource-poor countries, who have benefited from the generalized system of preferences (GSP), reflect the success of this system to a certain extent. Finally, accession to the WTO has not contributed toward an increase in natural resources' exports between members countries.

This paper is structured as follows. Section 2 reviews the literature related to the impact of the GATT/WTO. Section 3 presents the methodology used in the analysis, which is based principally on the cluster analysis and gravity models used for classification and estimation, respectively. Section 4 discusses the estimations' results. Section 5 concludes the paper. Finally, Section 6 presents policy implications. 


\section{Literature Review}

Given that the multilateral trade liberalization has been one of the aims of the GATT/WTO, it seems reasonable to believe that the GATT and the WTO have had a major impact on the world trade. This view was initially questioned by Rose (2004), who found no evidence of GATT/WTO's effects on bilateral trade flows. In recent years, several studies have attempted to address this question. The subsequent studies have provided mixed results not only about the overall impact but also about the channels through which the effect operates (the intensive and extensive margins of trade $)^{7}$ ) and about the potential asymmetries that may exist across groups of countries and periods.

In this section, we will review studies on the effects of the GATT/WTO on the international trade. We categorize the studies according to their objectives. First, we considered studies that investigated the overall impact of the GATT/WTO on the trade flows. Second, we reviewed studies that examined the impact of the GATT/WTO on the intensive and extensive margins of trade. Additionally, some authors studied the impact of the organization on the international trade, but at a disaggregated level. We also found studies that examined the possible asymmetric impact of WTO across countries, especially between industrialized and developing countries. Finally, we reviewed studies that revealed an occasional variation in the impact of the WTO.

\section{A. Impact of WTO on global trade}

The study by Rose (2004) is considered a starting point for examining the overall impact of the accession to the GATT/WTO on the international trade. Using a gravity model, based on a large panel dataset (178 countries examined over the period 1948 1999), he could not find a significantly positive effect of the GATT/WTO membership on trade flows. Later, Tomz et al. (2007) were the first that tried to comment on this unexpected conclusion. After updating Rose's dataset to include not only de jure but also de facto GATT/WTO membership, they concluded that the GATT/WTO substantially increased trade by $72 \%$ if both trading partners are GATT/WTO members and by $30 \%$ if only one participates. However, Rose (2004) and Tom et al. (2007) used average bilateral trade and ignored the multilateral resistance terms.

Subramanian and Wei (2007) focused on several asymmetries in the GATT/WTO system, utilizing a properly specified empirical framework that controls for multilateral resistance terms. Using bilateral import flows (unidirectional trade) from 1950 to 2000 at five-year intervals, they initially worsen Rose's results about the ineffectiveness of the GATT/WTO in increasing trade. They found that GATT/WTO membership has significant negative effects on trade when

7) We define the extensive margin as the number of varieties that are exported to each destination country, and the intensive margin as the average value of exports by variety, (Berthou and Fontagné 2008). 
membership is undifferentiated across groups of countries-average WTO members trade about $22 \%$ less than the average non-WTO members.

Eicher and Henn (2011) unified Rose (2004), Tomz et al. (2007), and Subramanian and Wei's (2007) approaches with the aim of minimizing several potential omitted variable biases. Their framework comprehensively controls for three sources of the omitted variable bias (multilateral resistance, unobserved bilateral heterogeneity, and individual preferential trade agreement (PTA) effects). They used the dataset by Subramanian and Wei (2007) with some adjustments; however, they did not find evidence of positive GATT/WTO trade effects. Moreover, they show that multilateral resistance controls are sufficient to negate GATT/WTO trade effects; according to their conclusion, all previous approaches indicate that GATT/WTO membership does not generate statistically significant trade effects.

In contrast, Chang and Lee (2011) reexamined the GATT/WTO's membership effect on bilateral trade flows using nonparametric methods, including pair-matching, permutation tests, and a Rosenbaum (2002) sensitivity analysis. Using Rose (2004) dataset, they showed that membership in the GATT/WTO produces significant trade-promoting effects that are robust to several restricted matching criteria, alternative GATT/WTO indicators, the non-random incidence of positive trade flows, the inclusion of multilateral resistance terms, and different matching methodologies.

Cheong et al. (2014) demonstrated that although accounting for multilateral resistance terms with country-year fixed effects can mitigate omitted variable bias, it will create a hitherto unnoticed multicollinearity problem that can lead to significantly different estimates with even miniscule changes in data coverage. The multicollinearity problem arises from the structural relationships between the two variables used throughout the literature to indicate whether one country (One in) in the pair belongs to the GATT/WTO or two countries (Both in) in the pair belong to the organization (with non-membership being the baseline) in the presence of exporter-time- and importer-time fixed effects. With data on 210 countries collected at five-year intervals for the period 1950 2000, the authors showed how the multicollinearity problem leads to fragile GATT/WTO effect estimates. They concluded that, in order to get precise estimates, only the (Both in) dummy must be included. Particularly, they found that joint GATT/WTO membership increases bilateral trade by $11 \%$.

The studies above used only the observations with positive trade, losing information crucial for assessing the impact of GATT/WTO on trade. Herz and Wagner (2011a) allowed for zero trade flows using the fixed-effect Poisson maximum-likelihood estimator, based on annual data for the period 1953 2006. Defining GATT/WTO membership on de facto, rather that de jure accession, they found that GATT/WTO promotes trade among members by $86 \%$, and trade between members and non-members is also fostered by around $40 \%$. However, an important limitation of their article is that they did not control for multilateral resistance terms. 
Other studies addressed the problem of zeros with alternative approaches, which are subject to more criticism. Roy (2011) estimated a theoretically consistent gravity equation that includes zero trade observations, by adding a small positive constant to all import flows to allow for the log-linearization of zero trade flows. He used data for the period 1950 2000 at five-year intervals; however, he did not find evidence that GATT/WTO countries significantly enhance their bilateral trade levels. Moreover, separate regressions for each decade reveal that formal membership in the GATT/WTO does not increase bilateral trade; the results remain the same even when the participation definition of Tomz et al. (2007) is considered.

Kohl and Trojanowska (2015) explored the effect of the different degrees of countries' involvement in the GATT/WTO on the volume of international trade; they also addressed the endogenous nature of trade policy in gravity equations with matching econometrics and included zero trade flows, similar to Roy (2011), by recording them from 0 to 1 . They used a panel dataset of 187 countries, covering the period 1960 2005; they found that the trade between two WTO members leads to a positive effect, while the effect is negative in the case of trade with an outsider.

\section{B. Impact of WTO on extensive and intensive margins of trade}

Other studies addressed the impact of the GATT/WTO on the international trade by examining the channels' impact - intensive and extensive margins of trade. Felbermayr and Kohler (2006) relied on the Tobit model to incorporate zero trade flows, showing that the consideration of the extensive margin generates evidence of a positive trade effect from membership. Moreover, Helpman et al. (2008) used a two-stage estimation procedure to investigate the extensive and intensive margins of the world trade; they found that the probability of trade increases by $15 \%$ if both countries belong to the GATT/WTO.

Liu (2009) used a fixed-effects Poisson pseudo-maximum likelihood (PPML) estimator to deal with the problem of zeros, which additionally allowed for the likely presence of heteroskedastic residuals (unlike the Tobit model). Based on an annual data over the period 1948 2003, he found that the GATT/WTO membership boosts trade among members by $60 \%$ (21\% through the extensive margin, and 39\% through the intensive margin), while trade with non-members is enhanced by $23 \%$ (15\% through the extensive margin, and $8 \%$ through the intensive margin).

Felbermayr and Kohler (2010) also accounted for the extensive margin of trade using a Poisson approach year-by-year and taking averages over four different time spans. By running Poisson pseudo-maximum likelihood (PPML) estimator (with and without zero trade observations), they found a strong variation across GATT/WTO periods. However, they broadly concluded that "the extensive margin does not prove a powerful line of defense for WTO membership 
as a trade-promoting force."

Dutt et al. (2013) examined the effect of GATT/WTO membership on the product-level extensive and intensive margins of trade. Using a six-digit bilateral trade data over the period 1988-2006, they found that the impact of WTO is concentrated on the extensive product margin of trade, that is, trade in goods that were not previously traded. Particularly, in their preferred specification (with time-varying- and county-pair fixed effects), WTO membership increases the extensive margin of exports by $25 \%$, whereas its negative impact on the volume of already-traded goods reduces the intensive margin by $7 \%$.

Bista (2015) extended Dutt et al.'s (2013) study, accounting for heteroskedasticity in trade data and zero trade flows using the PPML estimator. Based on disaggregated import data at the product level for 175 countries at five-year intervals over the period 1965 2005, he found a negative and statistically significant effect on total imports (both excluding and including zeros). Concerning the product-level trade margins, he found that, for both positive and zero trade flows, the effect of GATT/WTO membership on the extensive margin is negative, whereas this effect is not statistically significant for the intensive margin.

\section{Impact of WTO on disaggregated trade}

Some studies examined the impact of the GATT/WTO on the disaggregated bilateral trade and the product-type. Subramanian and Wei (2007) indicated that the GATT/WTO boosts trade in less-protected sectors, but not in agriculture and textile sectors.

Kim (2010) re-examined the Rose's (2004) conclusion using the same approach but with a different source of data in order to disaggregate the bilateral trade. Therefore, bilateral trade data is extracted from the COMTRADE over the period 1962 1999 for 173 countries. This source of bilateral trade allows the exclusion of agriculture, textile, and oil trade. He found that the membership in GATT/WTO increased trade by approximately $30 \%$ for member countries.

Engelbrecht and Pearce (2007) employed Rose's (2004) approach using trade data disaggregated by "factor intensity." The study used a sample of 46 countries over the period 1965 1997 and showed that the results for total trade are similar to those reported by Rose (2004). Additionally, the disaggregated estimates revealed that the GATT/WTO had a positive and statistically significant impact on trade in capital-intensive commodities, but no statistically significant impact on trade in other commodities.

Grant and Boys (2011) investigated the impact of membership in the GATT/WTO on the agricultural and non-agricultural bilateral trade. Using a large panel data comprising 215 countries over the period 1980 2004, they found that the GATT/WTO membership facilitates a 33\% increase in members' agricultural trade using the Rose (2004) model, a 161\% increase using the framework of Subramanian and Wei (2007), and a $114 \%$ increase when correcting 
for sample selection bias and the extensive margin of trade. In other words, participation in the GATT/WTO approximately doubles members' agricultural trade.

Mujahid and Kalkuhl (2016) investigated whether regional trade agreements and WTO have increased food trade among the participant countries. They used a gravity model for a large panel data on 162 countries collected for the period 1991 2012 at three-year intervals; the data also comprises bilateral food trade and total trade data derived from the COMTRADE via the World Integrated Trade Solution (WITS). The authors attempted to address some potential problems in the estimations, including multilateral trade resistances, zero trade values, and endogeneity. The results suggest that both the WTO and RTAs exerted significant positive effects on trade among the participant countries; however, this effect was not observed in the case of food trade. RTAs increased food trade among the participant countries.

\section{Impact of WTO on industrialized and developing countries}

Some of the previous studies also documented the possible asymmetric effect of GATT/WTO across countries, particularly between industrialized and developing countries. The study by Subramanian and Wei (2007) was the first study to focus on the asymmetries in the GATT/WTO system. They found that the GATT/WTO boosts trade in industrialized countries, but not in developing countries. Dutt et al. (2013) found that when the importer is a developed country, GATT/WTO membership boosts the extensive margin, whereas it has an insignificant impact on the intensive margin. In contrast, for developing countries' importers, they found that GATT/WTO's membership increases the extensive margin and significantly reduces the intensive margin. Felbermayr and Kohler (2010) documented that WTO increases the trade among developing countries' importers, but not among industrialized countries' importers. Grant and Boys (2011) concluded that middle and low income developing and least-developed economies, those with a vested interest in expanding agricultural exports, gain substantially from membership in the GATT/WTO. Bista (2015) showed differences in trade flows across countries based on their level of development; a positive impact on the extensive margin is only found in the case of trade between industrial and developing members, whereas GATT/WTO's members do not experience any positive impact on the intensive margin. Kohl (2017) found that, compared

to developing countries, developed countries gain more from GATT/WTO's membership. Finally, Mujahid and Kalkuhl (2016) found that although, on an average, the WTO is found to have negative implications on food trade, it benefits the developing countries more than the developed countries.

\section{E. Impact of WTO through trade rounds}

The results for sub-periods are also a source of controversy. Rose (2004) showed significant 
variation in the coefficients across trade rounds, whereas Tomz et al. (2007) found a positive and economically significant effect in every round, except the last one (1995 1999). Liu (2009) found a positive impact only during the pre-Kennedy years (1948 1963) and the post-Uruguay Round period (1995 2003). Felbermayr and Kohler (2010) revealed negative effects for the three time spans considered over the GATT period and a positive effect for the WTO period. Eicher and Henn (2011) and Roy (2011) reported, for each decade from 1950 to 2000, the absence of any significant trade effect of the GATT/WTO. In contrast, Herz and Wagner (2011a) showed that GATT/WTO substantially fostered bilateral trade during each of the five periods considered, especially during the pre-Kennedy rounds (1953 1963) and the Uruguay Round (1986 1994). Finally, Kohl (2017) estimated a negative effect until the Kennedy Round, zero effect until the Tokyo Round, and a significant positive effect until the Uruguay Round.

\section{Methodology}

Over the past 50 years, the gravity model has been considered one of the most successful empirical frameworks in the international economics for analyzing the determinates of bilateral trade flows. The gravity model can be justified by a variety of theories, including monopolistic competition (Helpman and Krugman 1985) and a Heckscher-Ohlin model with specialization (Anderson 1979, Deardorff 1998, Anderson and van Wincoop 2003).8) Empirically, the gravity model has been regularly used to estimate the ex-post (partial) impact of PTAs (for example, see Baier and Bergstrand 2007, Baier et al. 2007, Carrere 2006, Gil-Pareja et al. 2008a, Lee et al. 2008), currency unions (Rose 2000, Glick and Rose 2002, Micco et al. 2003, Gil-Pareja et al. 2008b), unilateral (non-reciprocal) preference regimes (Rose 2004, Mattoo et al. 2003, Tomz et al. 2007, Herz and Wagner 2011b), or, as in this study, the GATT/WTO membership (Rose 2004, Tomz et al. 2007, Subramanian and Wei 2007, Liu 2009, Felbermayr and Kohler 2010, Eicher and Henn 2011, Roy 2011, Chang and Lee 2011, Herz and Wagner 2011a, Dutt et al. 2013, Cheong et al. 2014, Kohl and Trojanowska 2015, Kohl 2015, Bista 2015).

This section is organized as follows. First, we introduce the basic gravity model, which will be used to assess the overall impact of the WTO on export flows. Second, we present the augmented gravity models set up to investigate the potential asymmetric impact of the WTO across countries. Subsequently, we explain the econometric issues related to the gravity models. Finally, we provide the data sources of variables and the methodology of classification used in the analysis.

8) See also, Bergstrand (1985 and 1989), Eaton and Kortum (2002), Evenett and Keller (2002) and Helpman et al. (2008) 


\section{A. Basic gravity model}

Our benchmark specification is the gravity Equation (1.1); it comprehensively accounts for multilateral resistance terms by including time-varying fixed effects and explains the self-selection endogeneity bias by integrating country-pair fixed effects as follows:

$$
X_{i j t}=\beta_{0}+\beta_{1} W T O_{i j t}+\beta_{2} P T A_{i j t}+\beta_{3} G S P_{i j t}+\gamma_{i t}+\delta_{j t}+\varphi_{i j}+\varepsilon_{i j t}
$$

where $(i)$ and $(j)$ denote trading partners, $(t)$ is year, and the variables are defined as follows:

$\begin{array}{ll}X_{i j t} & \text { Bilateral export flows from exporter }(i) \text { to importer }(j) \text { in year }(t), \\ \beta_{0} & \text { Constant term, } \\ W T O_{i j t} & \begin{array}{l}\text { Dummy variable takes the value } 1 \text { if both exporter }(i) \text { and importer }(j) \\ \text { are WTO/GATT members in year }(t),\end{array} \\ P T A_{i j t} & \begin{array}{l}\text { Dummy variable takes the value } 1 \text { if both exporter }(i) \text { and importer }(j) \\ \text { are part of a PTA in year }(t),\end{array} \\ G S P_{i j t} & \begin{array}{l}\text { Dummy variable takes the value } 1 \text { if the importer }(j) \text { grants preferences } \\ \text { under the GSP to the exporter }(i) \text { in year }(t),\end{array} \\ \gamma_{i t} & \text { Exporter-varying fixed effects, } \\ \delta_{j t} & \text { Importer-varying fixed effects, } \\ \varphi_{i j} & \text { Country-pair fixed effects, } \\ \varepsilon_{i j t} & \text { Error term. }\end{array}$

The inclusion of time-varying fixed effects for exporter $\left(\gamma_{i t}\right)$ and importer $\left(\delta_{j t}\right)$ in the gravity equation accounts for the multilateral price terms as well as the variation in all time-varying country variables, such as GDPs, population, most favored nation (MFN) tariffs of the exporter and importer, and unobservable trade costs/price indices. Moreover, the inclusion of the county-pair fixed effects $\left(\varphi_{i j}\right)$ controls for the impact of any time-invariant determinant of trade (observed or not) and resolves the endogeneity bias. Thus, time invariant pair-specific variables, such as distance, borders, common language, or colonial links, will be subsumed in these country-pair fixed effects, (Baier and Bergstrand 2007).

Following Santos Silva and Tenreyro (2006 and 2010), we deal with econometric problems resulting from both heteroskedastic residuals in log-linear gravity equations and the prevalence of zero bilateral trade flows by estimating the gravity equation in levels, rather than in logs, with the Poisson estimator (PPML). ${ }^{9)}$

Several studies treat the average of the two-way bilateral trade as the dependent variable, that is, the average of country $((i))$ exports to country $(j)$ and country $(i)$ imports to country

9) All econometric issues will be discussed in the next sub-section. 
(j) (for example, see Rose 2000, 2004, Glick and Rose 2002, Tomz et al. 2007). Baldwin and Taglioni (2006) called this procedure the silver medal mistake. They showed that the unidirectional bilateral trade value is more theoretically well-founded since the gravity model is a modified expenditure function that explains the value of spending by one country on the goods produced by another country. Therefore, in this study, we use the unidirectional trade data.

Concerning the coding issue, we use Rose's (2004) inclusive coding, in which both ( $W T O_{i j t}$ ) and $\left(G S P_{i j t}\right)$ variables take on the value "1" when the two conditions are fulfilled. Additionally, when the same trading partners are members of a common PTA $\left(P T A_{i j t}\right)$, a mutually inclusive coding assigns the value " 1 " to all the three dummies. Eicher and Henn (2011) indicated that the net effect generated by a mutually inclusive coding significantly reduces the risk of the omitted variable bias, while a mutually exclusive coding, which is used by Subramanian and Wei (2007), holds the danger of biasing WTO dummies. For further analysis, following Eicher and Henn (2011), we split the PTA $\left(P T A_{i j t}\right)$ into two dummy variables-regional integrations $\left(R T I_{i j t}\right)$ and bilateral agreements $\left(B T A_{i j t}\right)$, where:

\footnotetext{
$R T I_{i j t} \quad$ Dummy variable takes the value 1 if both exporter $(i)$ and importer $(j)$ belong to a common regional integration in year $(t)$,

$B T A_{i j t} \quad$ Dummy variable takes the value 1 if both exporter $(i)$ and importer $(j)$ are part of a common bilateral trade agreement in year $(t)$.
}

\section{B. Augmented gravity models}

The economic literature focused on the possible asymmetric effects of the GATT/WTO on the developed and developing countries. In general, the economic structures of developing countries are found to be dissimilar in terms of two dimensions. First, developing countries are heterogeneous in terms of their market growth-while some developing countries are characterized by emerging markets, some are not characterized by this feature.

Second, developing countries are not homogenous in terms of their natural resource endowment. This implies the existence of countries that have abundant natural resources and depend heavily on the production and exports of natural-resource commodities as well as countries that have scanty natural resources and rely on food and manufacturing.

In order to investigate the potential asymmetric effect of the WTO across countries, particularly across developing nations, we classified our sample of countries into the following five categories:

1. Developed countries; (dev)

2. Emerging natural resource-rich counties; (emg_rich)

3. Non-emerging natural resource-rich countries; (non_emg_rich)

4. Emerging natural resource-poor countries; (emg_poor) 


\section{Non-emerging natural resource-poor countries; (non_emg_poor)}

The first augmented model is set up to study the potential asymmetric effects of the WTO on countries as exporters. Therefore, we disaggregate WTO dummy variable $\left(W T O_{i j t}\right)$ into the following five dummies according to the category of the exporter:

$\begin{array}{ll}\text { Ex_dev_WTO } & \begin{array}{l}\text { Dummy variable takes the value } 1 \text { only if both exporter }(i) \text { and importer }(j) \text { are } \\ \text { members in the WTO in year }(t) \text { and exporter }(i) \text { is a developed country, }\end{array} \\ \text { Ex_emg_rich_WTO } & \begin{array}{l}\text { Dummy variable takes the value } 1 \text { only if both exporter }(i) \text { and importer }(j) \text { are } \\ \text { members in the WTO in year }(t) \text { and exporter }(i) \text { is an emerging natural-rich country, } \\ \text { natural resource-rich country, }\end{array} \\ & \begin{array}{l}\text { Dummy variable takes the value } 1 \text { only if both exporter }(i) \text { and importer }(j) \text { are } \\ \text { members in the WTO in year }(t) \text { and exporter }(i) \text { is a nonemerging natural }\end{array} \\ & \text { resource-rich country, } \\ & \begin{array}{l}\text { Dummy variable takes the value } 1 \text { only if both exporter }(i) \text { and importer }(j) \text { are } \\ \text { members in the WTO in year }(t) \text { and exporter }(i) \text { is an emerging natural resource-poor }\end{array} \\ & \text { country, natural resource-poor country, } \\ & \begin{array}{l}\text { Dummy variable takes the value } 1 \text { only if both exporter }(i) \text { and importer }(j) \text { are } \\ \text { members in the WTO in year }(t) \text { and exporter }(i) \text { is a nonemerging natural }\end{array} \\ \text { Ex_non_emg_poor_WTO } & \text { resource-poor country }\end{array}$

Further, in order to examine how the effects of regional integrations, bilateral agreements, and GSP are distributed among the five categories of countries, we also split other dummy variables $\left(R T I_{i j t}\right),\left(B T A_{i j t}\right)$, and $\left(G S P_{i j t}\right)$ according to the category of the exporter as follows:

Ex dev RTI

Ex_emg_rich_RTI

Ex_non_emg_rich_RTI

Ex_emg_poor_RTI

Ex_non_emg_poor_RTI

Ex_dev_BTA

Ex emg rich BTA

Ex_non_emg_rich_BTA
Dummy variable takes the value 1 only if both exporter $(i)$ and importer $(j)$ belong to a common regional integration in year $(t)$ and exporter $(i)$ is a developed country,

Dummy variable takes the value 1 only if both exporter $(i)$ and importer $(j)$ belong to a common regional integration in year $(t)$ and exporter $(i)$ is an emerging natural resource-rich country,

Dummy variable takes the value 1 only if both exporter $(i)$ and importer $(j)$ belong to a common regional integration in year $(t)$ and exporter $(i)$ is a non-emerging natural resource-rich country,

Dummy variable takes the value 1 only if both exporter $(i)$ and importer $(j)$ belong to a common regional integration in year $(t)$ and exporter $(i)$ is an emerging natural resource-poor country,

Dummy variable takes the value 1 only if both exporter $(i)$ and importer $(j)$ belong to a common regional integration in year $(t)$ and exporter $(i)$ is a non-emerging natural resource-poor country,

Dummy variable takes the value 1 only if both exporter $(i)$ and importer $(j)$ are part of a common bilateral trade agreement in year $(t)$ and exporter $(i)$ is a developed country,

Dummy variable takes the value 1 only if both exporter $(i)$ and importer $(j)$ are part of a common bilateral trade agreement in year $(t)$ and exporter $(i)$ is an emerging natural resource-rich country,

Dummy variable takes the value 1 only if both exporter $(i)$ and importer $(j)$ are part 
Ex_emg_poor_BTA

Ex_non_emg_poor_BTA

Ex_emg_rich_GSP

Ex_non_emg_rich_GSP

Ex_emg_poor_GSP

Ex_non_emg_poor_GSP of a common bilateral trade agreement in year $(t)$ and exporter $(i)$ is a non-emerging natural resource-rich country,

Dummy variable takes the value 1 only if both exporter $(i)$ and importer $(j)$ are part of a common bilateral trade agreement in year $(t)$ and exporter $(i)$ is an emerging natural resource-poor country,

Dummy variable takes the value 1 only if both exporter $(i)$ and importer $(j)$ are part of a common bilateral trade agreement in year $(t)$ and exporter $(i)$ is a non-emerging natural resource-poor country,

Dummy variable takes value 1 only if the importer $(j)$ grants preferences under the GSP to an emerging natural resource-rich exporter $(i)$ in year $(t)$,

Dummy variable takes the value 1 only if the importer $(j)$ grants preferences under the GSP to a non-emerging natural resource-rich exporter $(i)$ in year $(t)$,

Dummy variable takes the value 1 only if the importer $(j)$ grants preferences under the GSP to an emerging natural resource-poor exporter $(i)$ in year $(t)$,

Dummy variable takes the value 1 only if the importer $(j)$ grants preferences under the GSP to a non-emerging natural resource-poor exporter $(i)$ in year $(t)$.

We do not create Ex_dev_GSP because only developing countries can benefit from GSP, while developed countries serve as donors.

In the second augmented model, we aim to investigate the effect of WTO across countries, but, this time, as importers. Therefore, we disaggregate each dummy variable ( $\left.W T O_{i j t}\right),\left(R T I_{i j t}\right)$, and $\left(B T A_{i j t}\right)$ into five dummies according to the category of the importer. We do not split the importer $(j)$ of $\left(G S P_{i j t}\right)$ because GSP aims to support exports not imports.

\section{Econometric issues}

Our benchmarks consider several issues related to the estimation of the standard gravity equation. Recently, researchers have been struggling with the following three problems inherent in the gravity models: endogeneity, zero-trade flows, and multilateral trade resistance terms.

\section{Endogeneity}

The first problem that many analyses on trade policies have encountered in the gravity model involves the issue of potential endogeneity of RTAs; this issue arises when there is a potential reverse causality between RTAs and a higher level of bilateral trade between country pairs. According to the hypothesis of "natural trading partners" or "natural trading blocs," introduced by Krugman (1991), countries show a propensity to form RTAs with other partner countries when there are potentially higher trade volumes between them. Furthermore, there still are many unobserved factors between country pairs (except where the countries speak the same language and have a common colonial relationship) that may increase bilateral trade and promote the establishment of an RTA concurrently. Consequently, the estimated coefficients may become biased since the RTA dummy variables featuring the existence of the trade agreement are 
potentially correlated with the error term in the gravity equation. A majority of empirical studies using cross-sectional data and including dummy variables for trade agreements do not consider the issue of RTA endogeneity. In the past literature, Trefler (1993) and Lee and Swagel (1997) are the first works that attempt to adjust for the endogeneity of trade policies on a cross-section framework by using instrumental variables. Conversely, Magee (2003), find that the instrumental-variables approach does not efficiently adjust the issue of endogeneity bias of the RTA dummy variable that has a binary form, and it is hard to find instruments that are not likely correlated with the error term of the gravity equation. An alternative method of managing the potential endogeneity issue with RTAs is to estimate the gravity model, including both bilateral fixed effects for country pairs and time-varying fixed effects for exporter and importer countries. According to Baier and Bergstrand (2007), these fixed effects' specifications can deal with the issue of RTA endogeneity bias because of their ability to deal with the unobserved heterogeneity among pairs of countries, which are one of the most important sources of RTA endogeneity. Additionally, Head and Mayer (2014) also found that due to insufficient instrumental variables, panel data method, including country-pair fixed effects, can control for part of the potential RTA endogeneity bias. In principle, the same is also true for GATT/WTO's membership effects.

\section{Zero trade values}

The second consideration that needs to be specially addressed in analyzing sectoral trade is zero trade values. The zero trade values may more frequently emerge when estimating specific trade sectors. On the one hand, some of the zero trade flows reflect a random rounding error or random missing data. They may also come from the systematic rounding of very low reported values of bilateral trade. On the other hand, zero trade flows remaining in the database may naturally originate from the fact that bilateral trade does not occur over a period due to the remoteness of those countries, prohibitive transport costs, or the small size of the economies, as argued by Frankel (1997), Silva and Tenreyro (2006), and Helpman et al. (2008). Martin and Pham (2015) also found that most of the bilateral trade flows in aggregate trade data display a real absence of trade. The problem of zero trade flows is quite serious since almost $50 \%$ of the total observations on bilateral trade are zero in the dataset used by Silva and Tenreyro (2006), Helpman et al. (2008), and Burger et al. (2009). As a result, one need to take the problem of zero trade flows more seriously by using proper econometric techniques.

The conventional method for estimating gravity model is to keep the model in log-linear form. However, this approach is inappropriate as the log-linearized model is infeasible in the case of observations involving zero trade flow because the natural logarithm of zero is undefined. Hence, several ways have been proposed in the empirical literature to manage the zero-trade flow problem. One of the most prevalent ways involves the exclusion of zero trade from the 
dataset and, subsequently, the estimation of the gravity model on a truncated database of country pairs that consists of only positive bilateral trade flows. By omitting observations with zero trade, this method overlooks interesting and useful insights into the real nature of zero trade between countries and induces serious problems and biased results. This is because these zero trade flows are not randomly determined, as showed by Burger et al. (2009) and Martin and Pham (2015). Other studies choose to retain zero trade flows, but use some transformation involving the dependent variable, for instance, adding a small number to the zero-trade observation (value of 1 in most cases) to all trade flows before taking logarithms. Another method uses a Tobit model and keeps the observations involving zero trade flows.

Silva and Tenreyro (2006) argued that these methods will induce inconsistent estimates when the constant-elasticity model is used. They also pointed out that the standard methods used to estimate gravity models can lead to misleading estimated coefficients in the presence of heteroskedasticity, which appears inherently in trade data. If the problem of heteroskedasticity rises in the multiplicative model, then its transformation into log-linear form can lead to a more serious bias in the estimated elasticities. Hence, they do not recommend the estimation of the gravity model based on a log-linearized version. According to Silva and Tenreyro (2006), the PPML estimator, proposed by the authors, is a neutral method for solving the problem of zero trade flows. Especially, they found that the performance of the PPML estimator is not affected when the proportion of the dependent variable with zero trade is substantial. Since the gravity model is directly estimated from its multiplicative form, where the dependent variable is measured in levels, instead of linearizing the model by using logarithms, the zero-trade problem is well-handled. Moreover, they found that the PPML method seems to yield more robust and consistent results than the other econometric techniques in the presence of heteroskedasticity. The PPML estimator is also consistent with the general equilibrium condition when the estimation includes importer and exporter fixed effects (Fally 2015). PPML estimation can be estimated by solving the following first-order condition:

$$
\sum_{p}\left(X^{p}-\exp \left(Z^{p} \hat{\beta}\right)\right)=0
$$

where $p$ denotes country pairs; $X^{p}$ is the unidirectional trade (i.e., exports) between the country pairs, expressed in levels not in logarithms; and $Z^{p}$ is the full vector of the gravity equation, as defined in equation above.

Several recent empirical analyses on gravity model have included PPML method and praised the estimator as one of the new mainstays for assessing international trade, such as Westerlund and Wilhelmsson (2011), Anderson and Yotov (2012), and Martin and Pham (2015). 


\section{Multilateral trade resistance}

The last potential problem is related to the relative trade cost or the "multilateral trade resistance," as called by Anderson and van Wincoop (2003). Anderson and van Wincoop (2003) emphasized that the propensity of trade between two countries is not simply determined by the absolute trade cost between the two, but also by each country's trade cost towards its partners relative to their partners in the rest of the world. According to the authors, therefore, the three trade resistance factors in international trade are the bilateral trade barriers, the exporter country's trade resistance toward all other destinations, and the importer country's trade resistance toward all other trading partners. The two latter factors are called Anderson-van Wincoop's multilateral trade resistances (MTRs). For instance, the relative trade cost between two countries surrounded by oceans is different from that of the country pair surrounded by other exporting or importing countries. Ignoring MTRs could lead to biased estimation results (Anderson and van Wincoop 2003, Feenstra 2004). However, MTRs are difficult to measure as they are not directly observable. According to Baier and Bergstrand (2007), the inclusion of the bilateral- and time-varying fixed effects for the exporter and importer in the model overcomes the RTA endogeneity bias and addresses the Anderson and van Wincoop's multilateral resistance terms at the same time.

\section{Data and variables construction}

After introducing the models and econometric issues, we aim to explain how the variables are constructed, especially the dummies and their data sources. First, we provide the sources of the main variables, followed by the methodologies used to classify countries.

\section{Sources of variables}

The data comprises bilateral merchandise trade between 160 countries over the period 1980 2015; it is obtained at four-year intervals $(1980,1984, \ldots, 2012)$ and includes 2015 as the last year of the data.10)

The dependent variable $X_{i j t}$ is the nominal export flows from exporter $(i)$ to importer $(j)$ in year $\left.(t) .{ }^{11}\right)$ We estimated our basic gravity model using the following export flows: total

10) It is natural to expect that the adjustment of trade flows in response to trade policy changes will not be instantaneous. Hence, Trefler (2004) criticizes trade estimations pooled over consecutive years. In order to avoid this critique, researchers have used panel data with intervals instead of data pooled over consecutive years. For example, Trefler (2004) uses three-year intervals, Anderson and Yotov (2016) use four-year intervals, and Baier and Bergstrand (2007) use five-year intervals. Olivero and Yotov (2012) provide empirical evidence that gravity estimates obtained with three-year and five-year interval trade data are very similar, while estimations performed with panel samples pooled over consecutive years produce suspicious estimates of the trade cost elasticity parameters.

11) We used nominal trade values to avoid the bronze medal mistake. It refers to a common practice in the literature, namely, to deflate the nominal trade values by the US aggregate price index. Given that there are global trends 
exports, manufactures exports, food exports, agricultural raw materials exports, ore and metals exports, fuel exports, total natural resource exports, and total non-natural resource exports. However, our augmented gravity model is estimated using the total natural and non-natural resources' exports. We defined natural resource exports as provided by WTO (2010); in this case, the total exports comprise the exports of agricultural raw materials, ores and metals, fuels, and fish. ${ }^{12)}$ All export flows are taken from United Nations COMTRADE via the World Bank's platform: WITS (World Integrated Trade Solution).

Data on membership in the WTO is collected from World Trade Organization (WTO) website. We extracted data on regional trade integrations (RTIs) and bilateral trade agreements (BTA) from the Regional Trade Agreements Information System (RTA-IS) and completed from Mario Larch's Regional Trade Agreements Database. Our dataset covers 27 regional trade integrations and 340 bilateral trade agreements. ${ }^{13)}$ Finally, the data on GSP is obtained from CEPII Gravity Dataset.

\section{Classification issue}

Depending on our econometric models above, we first classify the countries according to their level of development. According to IMF (2015), 34 countries are classified as developed economies, and 23 countries as emerging markets. ${ }^{14)}$ According to Investopedia, an emerging market economy is "one in which the country is becoming a developed nation and is determined through many socio-economic factors."15) However, we use IMF's classification to classify our sample of countries into developed countries, emerging countries, and non-emerging countries.

Second, we classify countries, especially developing ones, according to their natural resource endowment. We review some methods of classification used in the related literature.

Concerning the IMF (2007), countries are considered rich in hydrocarbon and/or mineral

in inflation rates, such a procedure probably creates biases via spurious correlations (Baldwin and Taglioni 2006).

12) We used the Standard International Trade Classification (SITC), Revision 1 for disaggregated bilateral export flows; where Manufactures (SITC 5+6+7+8-68), Food (SITC 0+1+22+4-03), Agricultural Raw Materials (SITC 2-22-27-28), Ores \& Metals (SITC 27+28+68), Fuels (SITC 3) and Fish (STIC 03).

13) Regional integrations included Andean Community (CAN), ASEAN Free Trade Area (AFTA), Asia Pacific Trade Agreement (APTA), Baltic Free Trade Area (BAFTA), Central American Common Market (CACM), Central European Free Trade Agreement (CEFTA) 2006, Common Economic Zone (CEZ), Common Market for Eastern and Southern Africa (COMESA), Commonwealth of Independent States (CIS), Dominican Republic - Central America - United States Free Trade Agreement (CAFTA-DR), East African Community (EAC), Economic and Monetary Community of Central Africa (CEMAC), Economic Community of West African States (ECOWAS), Economic Cooperation Organization (ECO), European Union (EU) 28, Eurasian Economic Community (EAEC), European Economic Area (EEA), European Free Trade Association (EFTA), Gulf Cooperation Council (GCC), Latin American Integration Association (LAIA), North American Free Trade Agreement (NAFTA), Pan-Arab Free Trade Area (PAFTA),South Asian Free Trade Agreement (SAFTA), Southern African Customs Union (SACU), Southern African Development Community (SADC), Southern Common Market (MERCOSUR), and West African Economic and Monetary Union (WAEMU). The list of Bilateral agreements is available from the author upon request.

14) International Monetary Fund. (2015). World Economic Outlook: Adjusting to Lower Commodity Prices. Washington

15) Definition is taken from the website of Investopedia 
resources on the basis of the following criteria: (i) an average share of hydrocarbon and/or mineral fiscal revenues in total fiscal revenue of at least 25 percent during the period 2000 2005 or (ii) an average share of hydrocarbon and/or mineral export proceeds in total export proceeds of at least 25 percent during the period 2000 2005.16)

In a policy paper recently published by IMF (2012), using average data for 2006 2010, countries with at least 20 percent of their total exports in natural resources or those getting at least 20 percent of their revenue from natural resources are classified as resource-rich countries.

The World Bank (2008) classified the countries in MENA region into resource-rich and resource-poor countries, where resource-rich countries are those with large positive net oil exports. ${ }^{17)}$

Finally, the United Nations Conference on Trade and Development (UNCTAD) classified the countries into the following three groups: petroleum exporters, agricultural exporters, and minerals exporters. Petroleum exporters are countries whose average share of fuel exports was greater than $50 \%$ of their total exports and greater than 0.1 of the global fuel exports from 2013 2015. Agricultural products' exporters are those countries whose average share of exports of agricultural products was greater than $45 \%$ of their total exports and greater than $0.01 \%$ of the global exports of agricultural products from 2013 to 2015. Selected exporters of minerals and mining products are those countries whose average share of exports of ores, metals, precious stones, and non-monetary gold was greater than $50 \%$ of their total exports and greater than $0.01 \%$ of the global exports of ores, metals, precious stones, and nonmonetary gold of which from 2013 to 2015 . The three years used to calculate the averages change from time to time, and hence the classification of countries varies from one publication to another.

Based on the aforementioned, we can conclude that there is no common methodology used by the international organizations to classify countries into natural resource-rich and natural resource-poor countries. However, we can see that the average share of natural resource exports in total exports is used commonly as a main variable of classification. However, we note that the threshold used differs from one reference to another. We can also see that the chosen period or the number of years for calculating the averages differ from one method to another. Therefore, the methods that we reviewed above are based on an arbitrary selection and not on a theory or statistics. This lack of clarity motivated us to explore another method to classify countries according to their dependence on natural resources.

Therefore, we will apply a non-arbitrary method named cluster analysis to classify countries into resource-rich and resource-poor countries. This method is a statistical multivariate technique

16) This classification is used by Venables (2009) to point out that the natural resource wealth is distributed unevenly between Central Asia Regional Economic Cooperation (CAREC) countries.

17) This classification is used by Carrere et al. (2012) to verify Venables's (2009) theoretical predictions about the distribution of regional integration effects in MENA region. 
that helps to regroup countries (or other entities) in a way that minimizes the distance of the clustering variables between countries belonging to the same group, while maximizing it among groups. Several different approaches can be used for applying the cluster analysis. The most common approaches are the hierarchical method and the partitioning method (more precisely, $k$-means). However, each one follows a different approach for grouping the most similar objects into clusters. ${ }^{18)}$ We will apply the $k$-means clustering for two reasons. The first can be attributed to the ease of application; the second reason is that this method allows us to pre-determine the number of clusters desired to be created, unlike the hierarchical method. In our case, since we intend to classify countries exclusively into natural resource-rich countries and natural resource-poor countries, the k-means clustering method is consistent with this objective. The basic $k$-means clustering algorithm is defined as follows:

Step 1: We choose the number of clusters $k$.

Step 2: We make an initial selection of $k$ centroids.

Step 3: We assign each data element to its nearest centroid (in this way $k$ clusters are formed one for each centroid, where each cluster consists of all the data elements assigned to that centroid).

Step 4: We select a new centroid for each cluster.

Step 5: We repeat Step 3 until the centroids do not change (or some other convergence criterion is met).

Table 1. Variables of cluster analysis

\begin{tabular}{ll}
\hline Variable & \multicolumn{1}{c}{ Definition } \\
\hline & Share of natural resource exports in total exports over the period 1995 2015, in average. \\
& Natural resource exports are the sum of: \\
Natural resource & - Agricultural raw materials (SITC 2 less 22, 27 and 28). \\
exports $^{1}$ & - Ores and metals (SITC 27 $28+68)$ \\
& - Fuels (SITC 3). \\
& - Fish, crustaceans, molluscs and preparations thereof (SITC 03). \\
& Share of value added of natural resource sectors in total value added over the period 1995-2015, \\
& in average. \\
Value added of & Natural resource sectors include the following sectors: \\
natural resource & - Agriculture, Forestry, Fishing and Hunting \\
sectors & (ISIC Rev.3, divisions 01-05). \\
& - Mining, Quarrying, and Oil \& Gas Extraction \\
& (ISIC Rev.3, divisions 10-14).
\end{tabular}

(Note) ${ }^{1}$ We use the basic definition of natural resource exports of WTO

(Source) UNCTAD

18) For a complete and comprehensive outlook on Cluster Analysis, see Cliff, T. (2014). Exploratory data analysis in business and economics: An introduction using SPSS. Stata, and Excel: Springer, New York, 215. 
In order to classify the countries that depend heavily on natural resources using cluster analysis, we use two main input variables. First, we use the share of natural resources' exports in the total exports as an indicator of the specialization in natural resources. Second, we use the sum of value-added shares of agriculture and mining sectors in GDP as an indicator of the contribution of the natural resources sectors to GDP.

In order to classify the countries that depend heavily on natural resources using cluster analysis, we use two main input variables. First, we use the share of natural resources' exports in the total exports as an indicator of the specialization in natural resources. Second, we use the sum of value-added shares of agriculture and mining sectors in GDP as an indicator of the contribution of the natural resources sectors to GDP.

We applied $k$-means clustering method using two inputs variables-natural resource exports ( $\%$ total exports) and the value added of the natural resource sectors ( $\%$ total value added)-in order to classify 200 countries into natural resource-rich and natural resource-poor countries. ${ }^{19)}$ Figure 1 illustrates the distribution of countries by cluster, and Appendix 2 reports the results of cluster analysis to classify countries into resource-rich and resource-poor countries. ${ }^{20)}$ In order to investigate the impact of the WTO across countries, we combine the following two classifications:

1) Classification of countries according to the development level and growth of markets, using the IMF classification; 2) Classification of countries according to the abundance of natural resources, obtained by cluster analysis. Table 2 lists the five categories of countries depending on the above two classifications.

Figure 1. Classification of countries according to natural resource abundance

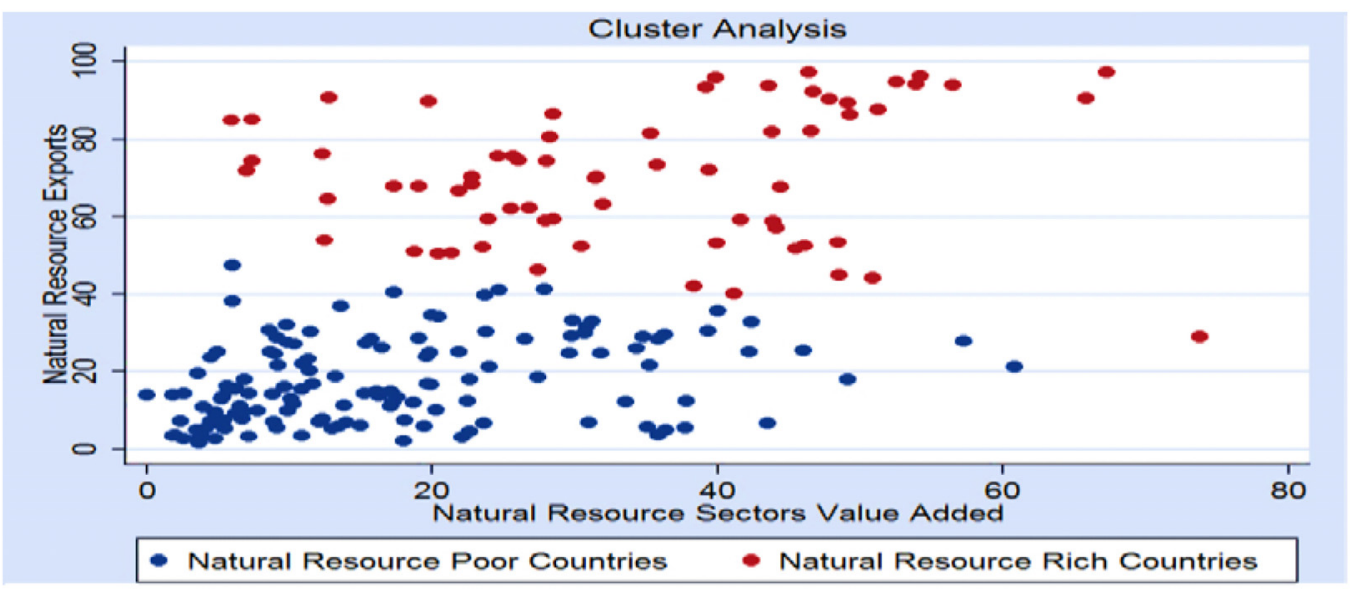

(Note) Appendix 2 reports the results of cluster analysis to classify countries into resource-rich and resource-poor countries. (Sources) UNCTAD

19) Appendix 1 lists the 200 counties included and the data used in the cluster analysis.

20) Concerning the adequacy of clustering, the analysis of variance (ANOVA) is provided in the Appendix 3. 


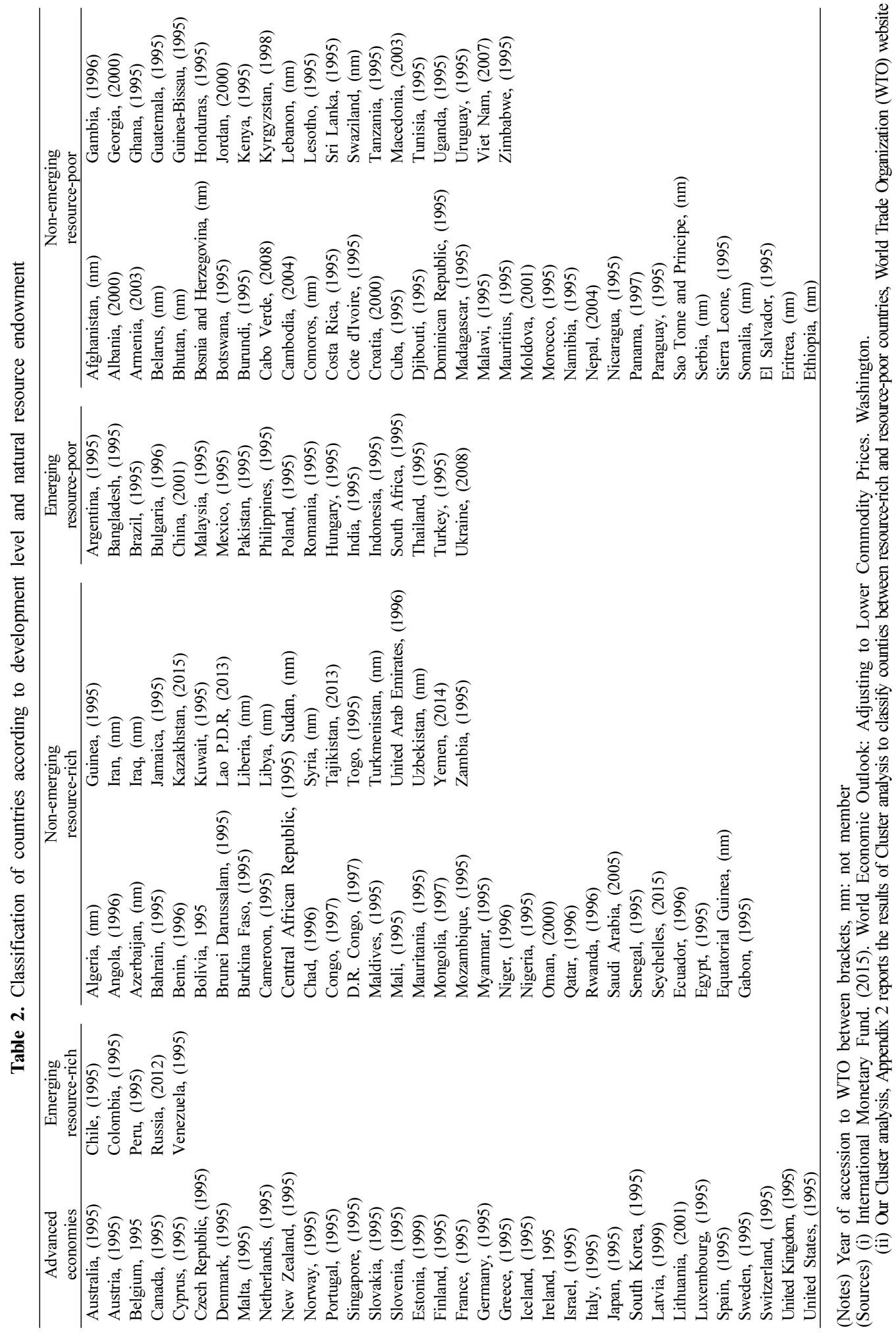




\section{Empirical Results and Discussion}

First, we discuss the results of our basic gravity model, which assesses the overall impact of the WTO on different specifications of export flows. Subsequently, we discuss the results of our augmented models that are set up to investigate the asymmetric impact of the WTO across countries.

\section{A. Overall impact of the WTO}

Table 3 shows that the overall impact of the WTO on total trade is insignificant. This is compatible with studies like Rose (2004), Eicher and Henn (2011), and Roy (2011). Meanwhile, we can see that WTO promotes trade in non-natural resources sectors-about $40 \%$ in manufacturing and about $20 \%$ in food.21) To a certain extent, this finding is in line with Kim (2010) who found that the GATT/WTO increased bilateral trade, except agriculture, textile, and oil trade. The aforementioned findings also coincide with that of Engelbrecht and Pearce (2007); they concluded that the GATT/WTO had a positive and statistically significant impact on trade in capital-intensive commodities (in manufacturing). Further, our results contradict the findings of Mujahid and Kalkuhl (2016) that the GATT/WTO does not have any positive effect on food sectors.

In contrast, the impact of WTO on natural resources sectors is not statistically significant. This can be explained by the low tariff imposed on raw materials. Thus, the liberalization of trade resulting from the accession to the WTO has no impact on natural resource flows between member countries. However, we do not share the same conclusion of Grant and Boys (2011) in terms of the impact of GATT/WTO on agricultural trade.22)

Concerning regional integrations, we can note that they have an overall positive impact on the total trade; this finding is compatible with most studies. Additionally, regional integration promoted trade in all sectors, except the agricultural raw materials sector.

The results indicate that the impact of bilateral trade agreements on the total trade is significant, unlike the finding of Eicher and Henn (2011) that bilateral trade agreements do not have any effect on trade. ${ }^{23)}$ At the sectoral level, bilateral agreement has boosted trade only in manufacturing sectors by $10 \%$. However, estimates show that their impact, in general, is less important when compared to WTO and regional integrations.

21) $40 \%=e x p^{0.344}-1$ and $20 \%=e x p^{0.191}-1$

22) Grant and Boys (2011) studied the impact of GATT/WTO on agricultural sectors, including food and agricultural raw materials sectors. Thus, the difference in results is due to the asymmetry in the definition of agricultural sectors; while we distinguish between food and agricultural raw materials, they treated both the sectors as a single sector.

23) Our dataset covers 340 bilateral trade agreements comparing to the study of Eicher and Henn (2011) which covers 65 bilateral agreements. 
Concerning the impact of GSP, our estimations share the same results of Eicher and Henn (2011) that GSP decreased trade.

Table 3. PPML panel estimates of aggregate trade effects of WTO, regional integrations, bilateral agreements and GSP on different trade flows. Sample period 1980 2015 at four-year intervals

\begin{tabular}{lcccccccc}
\hline VARIABLES & Total & $\begin{array}{c}\text { Non-Natural } \\
\text { Resource }\end{array}$ & $\begin{array}{c}\text { Natural } \\
\text { Resource }\end{array}$ & Manufactured & Food & $\begin{array}{c}\text { Agricultural } \\
\text { Raw Materials }\end{array}$ & Minerals & Energy \\
\hline WTO/GATT & 0.102 & $0.288^{* * *}$ & 0.0434 & $0.344^{* * *}$ & $0.191 *$ & 0.0601 & -0.303 & 0.00932 \\
& $(0.0819)$ & $(0.0767)$ & $(0.118)$ & $(0.0832)$ & $(0.110)$ & $(0.129)$ & $(0.187)$ & $(0.175)$ \\
Regional Integration & $0.330^{* * *}$ & $0.260^{* * *}$ & $0.359^{* * *}$ & $0.213^{* * *}$ & $0.542^{* * *}$ & -0.0542 & $0.311^{* * *}$ & $0.242^{* *}$ \\
& $(0.0306)$ & $(0.0286)$ & $(0.0679)$ & $(0.0291)$ & $(0.0696)$ & $(0.0800)$ & $(0.0604)$ & $(0.115)$ \\
Bilateral Agreement & $0.0917^{* * *}$ & $0.0992^{* * *}$ & 0.0688 & $0.106 * * *$ & -0.0544 & 0.0108 & 0.0311 & 0.0332 \\
& $(0.0287)$ & $(0.0284)$ & $(0.0593)$ & $(0.0318)$ & $(0.0398)$ & $(0.0494)$ & $(0.0499)$ & $(0.0833)$ \\
GSP & $-0.242^{* *}$ & $-0.185^{*}$ & 0.198 & -0.151 & -0.102 & -0.180 & $0.321^{*}$ & 0.243 \\
& $(0.120)$ & $(0.0956)$ & $(0.283)$ & $(0.100)$ & $(0.170)$ & $(0.144)$ & $(0.171)$ & $(0.329)$ \\
\hline Observations & 149,902 & 146,993 & 124,649 & 143,225 & 126,756 & 107,105 & 91,962 & 79,159 \\
$R$-squared & 0.995 & 0.996 & 0.982 & 0.996 & 0.986 & 0.984 & 0.983 & 0.981 \\
\hline
\end{tabular}

(Notes) (i) All regressions are performed using ppml_panel_sg STATA command written by Thomas Zylkin. This command enables faster computation of the many fixed effects required for panel PPML structural gravity estimation. Fixed effects used in all regressions are: county-pair fixed effects $\left(\varphi_{i j}\right)$ to address the endogeneity problem and to absorb all time-invariant variables among country pairs, and time-varying exporter $\left(\gamma_{i t}\right)$ and time-varying importer $\left(\delta_{j t}\right)$ fixed effects to control the multilateral resistance terms.

(ii) Standard errors (clustered by country-pair) and $t$-ratios in parentheses $* * * p<0.01,{ }^{* *} p<0.05, * p<0.1$.

(iii) The dependent variable is nominal value of bilateral export flows $\left(X_{i j t}\right)$.

(iv) We used Standard International Trade Classification (SITC), Revision 1 for disaggregated bilateral export flows; where Manufactures (SITC 5+6+7+8-68), Food (SITC 0+1+22+4-03), Agricultural Raw Materials (SITC 2-22-27-28), Ores \& Metals (SITC 27+28+68), Fuels (SITC 3) and Fish (STIC 03).

(v) Natural resources exports are the sum of Agricultural Raw Materials + Ores \& Metals + Fuels + Fish., as provided by WTO (2010).

(vi) Non-natural resource exports $=$ Total exports - Natural resource exports

\section{B. Asymmetric impact of WTO across developed countries, resource-rich countries, and resource-poor countries}

In this step of discussion, we estimated two augmented gravity models to analyze the potential asymmetric effects of WTO across countries. The first augmented model is set up to study the possible asymmetric effects of the WTO on countries as exporters. Therefore, we disaggregate each dummy variable $\left(W T O_{i j t}\right),\left(R T I_{i j t}\right),\left(B T A_{i j t}\right)$ and $\left(G S P_{i j t}\right)$ according to the category of the exporter. In the second augmented model, we aim to investigate the effects of WTO across countries as importers. Thus, we also disaggregate each dummy variable $\left(W T O_{i j t}\right),\left(R T I_{i j t}\right)$ and $\left(B T A_{i j t}\right)$ according to the category of the importer. Our categories of countries included in the analysis are developed countries, emerging natural resource-rich countries, non-emerging natural resource-rich countries, emerging natural resource-poor countries, and non-emerging natural resource-poor countries.

Table 4 provides results of the impact of the WTO across different categories of countries 
as exporters. First, we can note that the accession to the WTO has promoted non-natural resource exports of countries in all the categories, except the non-emerging resource-rich countries.

Additionally, results indicate that the emerging resource-rich countries receive maximum benefits from their accession to the WTO as they have been able to increase their non-natural resource exports to other WTO members by about $60 \%$. It must also be noted that, for the period 1995 2015, the average export concentration index of WTO member countries in this category was small, ranging between 20 and 30, except for Venezuela.24) This shows that their export structures are diversified and that they have been successful in following the import substitution/industrialization policies to some extent. ${ }^{25)}$

In contrast, the WTO has no impact on non-emerging resource-rich members in terms of increasing non-natural resource exports to other WTO members. This can be explained by the high export concentration index of this group. For the period 1995 2015, the average export concentration index of the WTO members classified in this group was more than 0.50.26) This shows how these countries still focus on exporting raw materials, and how the accession to the WTO, and previously to the GATT, did not promote exports in non-resource sectors.

Additionally, the WTO membership increased non-natural resource exports of emerging and non-emerging resource-poor countries. In fact, the impact on non-emerging resource-poor countries is greater. This is mainly due to the fact that countries classified as emerging resource-poor countries are considered large exporting countries. Most of these countries have been following trade liberalization policies since the $1990 \mathrm{~s}$, and therefore their economies are structured and oriented to export to global markets, especially to developed countries. Hence, the impact of the WTO on these countries seems to be less than that of the non-emerging poor countries.

The estimation results show that developed countries have increased their non-natural resource exports; this finding implies that the developed countries have also benefited from their accession to the WTO.

Nevertheless, accession to the WTO did not promote the natural resource exports of any category. This is due to the low tariff imposed on natural resource commodities.

Concerning the regional integration, we note that they have promoted the non-natural resource exports of countries in all categories, except the emerging resource-rich countries. In contrast, results indicate that regional integration contributed toward boosting intra-regional exports in non-natural resource sectors of non-emerging resource-rich countries, and thereby may help to diversify their economies.

24) For export concentration index, see Appendix 1.

25) All countries classified as emerging resource-rich are South American countries except Russian Federation, see Table 2. These countries largely adopted import substitution policies in the $70 \mathrm{~s}$ and $80 \mathrm{~s}$ and they are also former GATT members.

26) Additionally, for the period 1995 2015, the average export concentration index of 30 WTO members classified in this group exceeded 0.40 . 
Table 4. PPML panel estimates of trade effect of WTO, Regional integrations, Bilateral agreements and GSP across exporters. Sample period 1980 2015 at four-year intervals

\begin{tabular}{|c|c|c|c|}
\hline Variable & Definition & $\begin{array}{l}\text { Total trade } \\
\text { excluding natural } \\
\text { resource sectors }\end{array}$ & $\begin{array}{c}\text { Natural } \\
\text { Resource } \\
\text { Sectors }\end{array}$ \\
\hline$E x \_d e v \_W T O$ & $\begin{array}{l}\text { Exporter }(i) \text { and importer }(j) \text { are members in WTO, } \\
\text { exporter is a developed country }\end{array}$ & $\begin{array}{l}0.278 * * * \\
(0.0923)\end{array}$ & $\begin{array}{l}-0.0328 \\
(0.145)\end{array}$ \\
\hline Ex_emg_rich_WTO & $\begin{array}{l}\text { Exporter }(i) \text { and importer }(j) \text { are members in WTO, } \\
\text { exporter is an emerging resource-rich country }\end{array}$ & $\begin{array}{c}0.473 * * * \\
(0.159)\end{array}$ & $\begin{array}{c}0.108 \\
(0.191)\end{array}$ \\
\hline Ex_non_emg_rich_WTO & $\begin{array}{l}\text { Exporter }(i) \text { and importer }(j) \text { are members in WTO, } \\
\text { exporter is a non-emerging resource-rich country }\end{array}$ & $\begin{array}{c}0.0877 \\
(0.0963)\end{array}$ & $\begin{array}{c}0.236 \\
(0.220)\end{array}$ \\
\hline Ex_emg_poor_WTO & $\begin{array}{l}\text { Exporter }(i) \text { and importer }(j) \text { are members in WTO, } \\
\text { exporter }(i) \text { is an emerging resource-poor country }\end{array}$ & $\begin{array}{l}0.227 * * \\
(0.0901)\end{array}$ & $\begin{array}{l}0.0735 \\
(0.152)\end{array}$ \\
\hline Ex_non_emg_poor_WTO & $\begin{array}{l}\text { Exporter }(i) \text { and importer }(j) \text { are members in WTO, } \\
\text { exporter }(i) \text { is a non-emerging resource-poor country }\end{array}$ & $\begin{array}{c}0.374 * * * \\
(0.138) \\
\end{array}$ & $\begin{array}{l}-0.232 \\
(0.199)\end{array}$ \\
\hline$E x \_d e v \_R T I$ & $\begin{array}{l}\text { Exporter }(i) \text { and importer }(j) \text { are members in RTI, } \\
\text { exporter is a developed country }\end{array}$ & $\begin{array}{l}0.226 * * * \\
(0.0340)\end{array}$ & $\begin{array}{c}0.409 * * * \\
(0.0924)\end{array}$ \\
\hline Ex_emg_rich_RTI & $\begin{array}{l}\text { Exporter }(i) \text { and importer }(j) \text { are members in RTI, } \\
\text { exporter is an emerging resource-rich country }\end{array}$ & $\begin{array}{c}0.201 \\
(0.215) \\
\end{array}$ & $\begin{array}{c}0.246 \\
(0.359) \\
\end{array}$ \\
\hline Ex_non_emg_rich_RTI & $\begin{array}{l}\text { Exporter }(i) \text { and importer }(j) \text { are members in RTI, } \\
\text { exporter is a non-emerging resource-rich country }\end{array}$ & $\begin{array}{c}0.310^{* * *} \\
(0.215)\end{array}$ & $\begin{array}{c}0.246 \\
(0.359)\end{array}$ \\
\hline Ex_emg_poor_RTI & $\begin{array}{l}\text { Exporter }(i) \text { and importer }(j) \text { are members in RTI, } \\
\text { exporter }(i) \text { is an emerging resource-poor country }\end{array}$ & $\begin{array}{l}0.326 * * * \\
(0.0922)\end{array}$ & $\begin{array}{c}0.322 * * \\
(0.126)\end{array}$ \\
\hline Ex_non_emg_poor_RTI & $\begin{array}{l}\text { Exporter }(i) \text { and importer }(j) \text { are members in RTI, } \\
\text { exporter }(i) \text { is a non-emerging resource-poor country }\end{array}$ & $\begin{array}{l}0.375 * * * \\
(0.0667)\end{array}$ & $\begin{array}{c}0.192 \\
(0.139)\end{array}$ \\
\hline$E x \_d e v \_B T A$ & $\begin{array}{l}\text { Exporter }(i) \text { and importer }(j) \text { are members in BTA, } \\
\text { exporter is a developed country }\end{array}$ & $\begin{array}{l}0.0682 * * \\
(0.0340)\end{array}$ & $\begin{array}{c}0.100 \\
(0.0976)\end{array}$ \\
\hline Ex_emg_rich_BTA & $\begin{array}{l}\text { Exporter }(i) \text { and importer }(j) \text { are members in BTA, } \\
\text { exporter is an emerging resource-rich country }\end{array}$ & $\begin{array}{c}0.0715 \\
(0.0858)\end{array}$ & $\begin{array}{l}0.0440 \\
(0.113)\end{array}$ \\
\hline Ex_non_emg_rich_BTA & $\begin{array}{l}\text { Exporter }(i) \text { and importer }(j) \text { are members in BTA, } \\
\text { exporter is a non-emerging resource-rich country }\end{array}$ & $\begin{array}{l}0.444 * \\
(0.255) \\
\end{array}$ & $\begin{array}{l}0.0410 \\
(0.179)\end{array}$ \\
\hline Ex_emg_poor_BTA & $\begin{array}{l}\text { Exporter }(i) \text { and importer }(j) \text { are members in BTA, } \\
\text { exporter }(i) \text { is an emerging resource-poor country }\end{array}$ & $\begin{array}{l}0.168 * * * \\
(0.0479)\end{array}$ & $\begin{array}{c}0.0568 \\
(0.0851)\end{array}$ \\
\hline Ex_non_emg_poor_BTA & $\begin{array}{l}\text { Exporter }(i) \text { and importer }(j) \text { are members in BTA, } \\
\text { exporter }(i) \text { is a non-emerging resource-poor country }\end{array}$ & $\begin{array}{l}0.151 * * * \\
(0.0570)\end{array}$ & $\begin{array}{l}0.0651 \\
(0.180)\end{array}$ \\
\hline Ex_emg_rich_GSP & $\begin{array}{l}\text { Importer }(j) \text { grants preferences under GSP to an emerging } \\
\text { resource-rich exporter }(i)\end{array}$ & $\begin{array}{r}-0.760 * \\
(0.451)\end{array}$ & $\begin{array}{c}1.276^{* * * *} \\
(0.391)\end{array}$ \\
\hline Ex_non_emg_rich_GSP & $\begin{array}{l}\text { Importer }(j) \text { grants preferences under GSP to an } \\
\text { non-emerging resource-rich exporter }(i)\end{array}$ & $\begin{array}{l}0.0862 \\
(0.283)\end{array}$ & $\begin{array}{c}0.201 \\
(0.409)\end{array}$ \\
\hline Ex_emg_poor_GSP & $\begin{array}{l}\text { Importer }(j) \text { grants preferences under GSP to an emerging } \\
\text { resource-poor exporter }(i)\end{array}$ & $\begin{array}{c}-0.409 * * * \\
(0.195) \\
\end{array}$ & $\begin{array}{l}-0.452 \\
(0.298) \\
\end{array}$ \\
\hline Ex_non_emg_poor_GSP & $\begin{array}{l}\text { Importer }(j) \text { grants preferences under GSP to an } \\
\text { non-emerging resource-poor country exporter }(i)\end{array}$ & $\begin{array}{c}0.578 * * * \\
(0.208)\end{array}$ & $\begin{array}{l}0.0291 \\
(0.456)\end{array}$ \\
\hline Observations & & 147,053 & 124,649 \\
\hline$R$-squared & & 0.996 & 0.982 \\
\hline
\end{tabular}

(Notes) (i) All regressions are performed using ppml_panel_sg STATA command written by Thomas Zylkin. This command enables faster computation of the many fixed effects required for panel PPML structural gravity estimation. Fixed effects used in all regressions are: county-pair fixed effects $\left(\varphi_{i j}\right)$ to address the endogeneity problem and to absorb 
all time-invariant variables among country pairs, and time-varying exporter $\left(\gamma_{i t}\right)$ and time-varying importer $\left(\delta_{j t}\right)$ fixed effects to control the multilateral resistance terms.

(ii) Standard errors (clustered by country-pair) and $t$-ratios in parentheses $* * * p<0.01, * * p<0.05$, * $p<0.1$.

(iii) The dependent variable is nominal value of bilateral export flows $\left(X_{i j t}\right)$.

(iv) We used Standard International Trade Classification (SITC), Rev 1

(v) Natural resources exports are the sum of Agricultural Raw Materials(SITC 2-22-27-28) + Ores \& Metals(SITC

$27+28+68)+$ Fuels(SITC 3) + Fish(SITC 03), as provided by WTO (2012).

(vi) Non-natural resource exports $=$ Total exports - Natural resource exports

Concerning resource-poor countries, estimation results show that regional integrations have contributed toward an increase in intra-regional exports in non-natural resource sectors of both emerging- and non-emerging resource-poor countries. It must be noted that the impact of regional integrations is more important compared to the effect of WTO on these countries. Further, these countries benefited more from the regional integration, compared to resource-rich countries. ${ }^{27)}$

Results indicated that regional integration increased exports of developed countries in both natural resources- and non-natural resource sectors. ${ }^{28)}$

Regarding the bilateral agreements, all countries increased their non-natural resource exports to their bilateral partners after signing these agreements, with the exception of emerging resource-rich countries. However, results indicate that non-emerging resource-rich countries are the greatest beneficiaries. In general, compared to the WTO and regional integrations, the impact of this type of trade agreement is less important, especially in developed- and resource-poor countries. Bilateral agreements have also not contributed also to an increase in the natural resource exports of any category of countries.

Finally, we note that only non-emerging resource-poor countries have benefited from GSP. This confirms the principle objective of GSP to help developing countries, particularly least developing countries, to increase their exports to major export markets. ${ }^{29)}$

Table 5 provides results of the impact of the WTO accession on countries as importers. We note that the WTO has contributed to increased non-natural resource imports of all categories from WTO members, and also that the emerging resource-rich countries are the greatest beneficiaries. We note that regional integration has also contributed to increase intra-regional imports in non-natural resource sectors. In addition, results indicate that both emerging and non-emerging resource-poor countries increased intra-reginal imports in natural resource sectors from their regional partners. Finally, bilateral agreements increased the bilateral-imports in non-natural resource sectors of both categories of resource-poor countries.

27) We also noted that regional integration stimulated intra-regional exports in natural resources sectors.

28) The shares of intra-regional trade in natural resource exports of the more industrialized WTO regions in 2008 were as follows: 82 percent, 78 percent, and 62 percent for Europe, Asia, and North America. Meanwhile, resource-dominant regions of the CIS, Africa, and Middle East had very low intra-regional trade shares of 12 percent, 5 percent and 2 percent, respectively. Latin America was again between the extremes, with an intra-regional trade share of 22 percent, (WTO 2010).

29) Most of countries classified as non-emerging resource-poor countries are least developed countries. 
Table 5. PPML panel estimates of trade effect of WTO, Regional integrations, Bilateral agreements and GSP across importers. Sample period 1980 2015 at four-year intervals

\begin{tabular}{|c|c|c|c|}
\hline Variable & Definition & $\begin{array}{l}\text { Total trade } \\
\text { excluding natural } \\
\text { resource sectors }\end{array}$ & $\begin{array}{c}\text { Natural } \\
\text { Resource } \\
\text { Sectors }\end{array}$ \\
\hline Im_dev_WTO & $\begin{array}{l}\text { Exporter }(i) \text { and importer }(j) \text { are members in WTO, } \\
\text { exporter is a developed country }\end{array}$ & $\begin{array}{l}0.231 * * * \\
(0.0941)\end{array}$ & $\begin{array}{l}0.0858 \\
(0.132)\end{array}$ \\
\hline Im_emg_rich_WTO & $\begin{array}{l}\text { Exporter }(i) \text { and importer }(j) \text { are members in WTO, } \\
\text { exporter is an emerging resource-rich country }\end{array}$ & $\begin{array}{c}0.472 * * * \\
(0.123)\end{array}$ & $\begin{array}{c}0.434 \\
(0.275)\end{array}$ \\
\hline Im_non_emg_rich_WTO & $\begin{array}{l}\text { Exporter }(i) \text { and importer }(j) \text { are members in WTO, } \\
\text { exporter is a non-emerging resource-rich country }\end{array}$ & $\begin{array}{l}0.284 * * \\
(0.129)\end{array}$ & $\begin{array}{l}0.419^{*} \\
(0.249)\end{array}$ \\
\hline Im_emg_poor_WTO & $\begin{array}{l}\text { Exporter }(i) \text { and importer }(j) \text { are members in WTO, } \\
\text { exporter }(i) \text { is an emerging resource-poor country }\end{array}$ & $\begin{array}{l}0.366^{* * * *} \\
(0.0849)\end{array}$ & $\begin{array}{l}-0.133 \\
(0.109)\end{array}$ \\
\hline Im_non_emg_poor_WTO & $\begin{array}{l}\text { Exporter }(i) \text { and importer }(j) \text { are members in WTO, } \\
\text { exporter }(i) \text { is a non-emerging resource-poor country }\end{array}$ & $\begin{array}{c}0.345^{* * *} \\
(0.100)\end{array}$ & $\begin{array}{l}-0.144 \\
(0.166)\end{array}$ \\
\hline Im_dev_RTI & $\begin{array}{l}\text { Exporter }(i) \text { and importer }(j) \text { are members in RTI, } \\
\text { exporter is a developed country }\end{array}$ & $\begin{array}{l}0.221 * * * \\
(0.0441)\end{array}$ & $\begin{array}{r}0.366^{* * *} \\
(0.0845)\end{array}$ \\
\hline Im_emg_rich_RTI & $\begin{array}{l}\text { Exporter }(i) \text { and importer }(j) \text { are members in RTI, } \\
\text { exporter is an emerging resource-rich country }\end{array}$ & $\begin{array}{c}1.109 * * * \\
(0.229)\end{array}$ & $\begin{array}{l}-0.772 \\
(0.493)\end{array}$ \\
\hline Im_non_emg_rich_RTI & $\begin{array}{l}\text { Exporter }(i) \text { and importer }(j) \text { are members in RTI, } \\
\text { exporter is a non-emerging resource-rich country }\end{array}$ & $\begin{array}{l}0.203 * * \\
(0.0893)\end{array}$ & $\begin{array}{c}0.575^{* * *} \\
(0.203)\end{array}$ \\
\hline Im_emg_poor_RTI & $\begin{array}{l}\text { Exporter }(i) \text { and importer }(j) \text { are members in RTI, } \\
\text { exporter }(i) \text { is an emerging resource-poor country }\end{array}$ & $\begin{array}{l}0.332 * * * \\
(0.0620)\end{array}$ & $\begin{array}{l}0.323^{*} \\
(0.190) \\
\end{array}$ \\
\hline Im_non_emg_poor_RTI & $\begin{array}{l}\text { Exporter }(i) \text { and importer }(j) \text { are members in RTI, } \\
\text { exporter }(i) \text { is a non-emerging resource-poor country }\end{array}$ & $\begin{array}{l}0.199 * * * \\
(0.0489)\end{array}$ & $\begin{array}{l}0.323^{*} \\
(0.189)\end{array}$ \\
\hline Im_dev_BTA & $\begin{array}{l}\text { Exporter }(i) \text { and importer }(j) \text { are members in BTA, } \\
\text { exporter is a developed country }\end{array}$ & $\begin{array}{c}0.0608 \\
(0.0423)\end{array}$ & $\begin{array}{c}0.0789 \\
(0.0766)\end{array}$ \\
\hline Im_emg_rich_BTA & $\begin{array}{l}\text { Exporter }(i) \text { and importer }(j) \text { are members in BTA, } \\
\text { exporter is an emerging resource-rich country }\end{array}$ & $\begin{array}{c}0.0460 \\
(0.0677)\end{array}$ & $\begin{array}{c}0.750 * * * \\
(0.232)\end{array}$ \\
\hline Im_non_emg_rich_BTA & $\begin{array}{l}\text { Exporter }(i) \text { and importer }(j) \text { are members in BTA, } \\
\text { exporter is a non-emerging resource-rich country }\end{array}$ & $\begin{array}{l}-0.0974 \\
(0.0893)\end{array}$ & $\begin{array}{l}-0.0402 \\
(0.194)\end{array}$ \\
\hline Im_emg_poor_BTA & $\begin{array}{l}\text { Exporter }(i) \text { and importer }(j) \text { are members in BTA, } \\
\text { exporter }(i) \text { is an emerging resource-poor country }\end{array}$ & $\begin{array}{l}0.152 * * * \\
(0.0354)\end{array}$ & $\begin{array}{l}0.00198 \\
(0.0908)\end{array}$ \\
\hline Im_non_emg_poor_BTA & $\begin{array}{l}\text { Exporter }(i) \text { and importer }(j) \text { are members in BTA, } \\
\text { exporter }(i) \text { is a non-emerging resource-poor country }\end{array}$ & $\begin{array}{l}0.264 * * * \\
(0.0756)\end{array}$ & $\begin{array}{l}0.0587 \\
(0.150)\end{array}$ \\
\hline$G S P$ & Importer $(j)$ grants preferences under GSP to an exporter $(i)$ & $\begin{array}{l}-0.175^{*} \\
(0.0958)\end{array}$ & $\begin{array}{c}0.186 \\
(0.283)\end{array}$ \\
\hline Observations & & 147,053 & 124,649 \\
\hline$R$-squared & & 0.996 & 0.982 \\
\hline
\end{tabular}

(Notes) (i) All regressions are performed using ppml_panel_sg STATA command written by Thomas Zylkin. This command enables faster computation of the many fixed effects required for panel PPML structural gravity estimation. Fixed effects used in all regressions are: county-pair fixed effects $\left(\varphi_{i j}\right)$ to address the endogeneity problem and to absorb all time-invariant variables among country pairs, and time-varying exporter $\left(\gamma_{i t}\right)$ and time-varying importer $\left(\delta_{j t}\right)$ fixed effects to control the multilateral resistance terms.

(ii) Standard errors (clustered by country-pair) and $t$-ratios in parentheses $* * * p<0.01, * * p<0.05$, * $p<0.1$.

(iii) The dependent variable is nominal value of bilateral export flows $\left(X_{i j t}\right)$.

(iv) We used Standard International Trade Classification (SITC), Rev 1

(v) Natural resources exports are the sum of Agricultural Raw Materials(SITC 2-22-27-28) + Ores \& Metals(SITC

$27+28+68)+$ Fuels(SITC 3) + Fish(SITC 03), as provided by WTO (2012).

(vi) Non-natural resource exports $=$ Total exports - Natural resource exports 
Table 6 shows the percentage increase in non-natural resource exports and imports by each category for each type of international trade regulation.

Table 6. Percentage increase in non-natural resource exports and imports by each category. Sample period $1980-2015$ at four-year interval

\begin{tabular}{|c|c|c|c|c|c|c|c|}
\hline \multirow[b]{2}{*}{ Category } & \multicolumn{2}{|c|}{$\begin{array}{l}\text { World Trade } \\
\text { Organization } \\
\text { (WTO) }\end{array}$} & \multicolumn{2}{|c|}{$\begin{array}{l}\text { Regional Trade } \\
\text { Integration } \\
\text { (RTI) }\end{array}$} & \multicolumn{2}{|c|}{$\begin{array}{l}\text { Bilateral Trade } \\
\text { Agreements } \\
\text { (BTA) }\end{array}$} & \multirow{2}{*}{$\begin{array}{c}\text { Generalized } \\
\text { System of } \\
\text { Preferences } \\
(\mathrm{GSP}) \\
\text { Export }\end{array}$} \\
\hline & Exports & Imports & Exports & Imports & Exports & Imports & \\
\hline Developed countries & $32.05 \%$ & $25.99 \%$ & $25.36 \%$ & $24.73 \%$ & $7.06 \%$ & - & - \\
\hline Emerging resource - rich countries & $60.48 \%$ & $60.32 \%$ & - & $203.13 \%$ & - & - & $-53.23 \%$ \\
\hline Non-emerging resource - rich countries & - & $32.84 \%$ & $36.34 \%$ & $22.51 \%$ & $55.89 \%$ & - & $0.00 \%$ \\
\hline Emerging resource - poor countries & $25.48 \%$ & $44.20 \%$ & $38.54 \%$ & $39.38 \%$ & $18.29 \%$ & $16.42 \%$ & $-33.57 \%$ \\
\hline Non-emerging resource - poor countries & $45.35 \%$ & $41.20 \%$ & $45.50 \%$ & $22.02 \%$ & $16.30 \%$ & $30.21 \%$ & $78.25 \%$ \\
\hline \multicolumn{8}{|c|}{$\begin{array}{l}\text { (Notes) (i) Calculated using estimates reported in Tables } 4 \text { and } 5 \text { in this paper. } \\
\text { (ii) These effects are calculated as exp(coeff)-1 } \\
\text { (iii) The dependent variable is nominal value of bilateral export flows }\left(X_{i j t}\right) \text {. } \\
\text { (iv) We used Standard International Trade Classification (SITC), Rev } 1 \\
\text { (v) Natural resources exports = Agricultural Raw Materials(SITC 2-22-27-28) + Ores \& Metals(SITC 27+28+68) } \\
+ \text { Fuels(SITC 3) + Fish(SITC 03), as provided by WTO (2012). } \\
\text { (vi) Non-natural resource exports = Total exports - Natural resource exports }\end{array}$} \\
\hline
\end{tabular}

\section{Conclusion}

This study is considered an extension of the studies based on the effects of the WTO. Previous studies focused on examining the impact of the WTO between developed and developing countries, which is considered one of the main aspects of this scope. However, we showed that developing countries are not homogenous in several aspects. They differ in terms of market growth and their dependence on natural resources. The study had two main objectives. First, it examined the overall impact of the WTO on international trade. Second, it investigated the potential asymmetric impact of the WTO across countries, especially focusing on developing countries. After discussing the results of the estimates, we can present some conclusions.

First, our results indicated that the WTO did not impact any type of natural resource commodities, while it boosted trade in manufacturing and food sectors.

With respect to natural resource-rich countries, the impact of the WTO depends on the market growth in these countries. Our estimation shows that the WTO has a significant and positive impact on resource-rich countries that have emerging markets and diversified export structures-these countries have received maximum benefits from their accession to the WTO. In contrast, other forms of international trade regulation, particularly regional integration and bilateral agreements, have not increased the exports of emerging resource-rich countries toward 
their regional or bilateral partners. This shows that emerging resource-rich countries are more inclined toward full trade liberalization and exports to the global markets. Furthermore, WTO did not promote the exports of non-emerging resource-rich countries. These countries heavily depend on exporting natural resources and their export structures are not diversified enough. On the one hand, regional integration and bilateral agreements stimulated their non-resource exports. This implies that non-emerging resource-rich countries are more oriented toward regional markets. Therefore, we can conclude that, owing to the export diversification and an improvement in the competitiveness of countries in the first category, these countries benefited from the accession to the WTO. On the other hand, owing to the lack of competitiveness, the second category of countries benefited more from regional and bilateral agreements than the WTO.

However, the impact of WTO is significant and positive across resource-poor countries. Both emerging resource-poor- and non-emerging resource-poor countries have unevenly benefited from their accession to the WTO. Results indicated that emerging markets benefited less from the accession. Since they have been adopting trade liberalization policies that essentially rely on exports, their accession to the WTO has not affected their trade patterns. Concerning regional integrations, we also note that they have a slightly more positive effect on both categories when compared to WTO's impact. This shows the importance of establishing trade blocks for resource-poor countries. Bilateral agreements have also contributed toward an increase in exports of both resource-poor categories, but to a lesser extent. The results also showed that only non-emerging resource-poor countries benefiting from the GPS reflect the success of this system to a certain extent.

Finally, accession to the WTO has not promoted natural exports between members countries mainly, as mentioned before, due to the low tariffs imposed on them. Therefore, the dramatic increase in the share of natural resources in international trade has been affected by other factors like population growth, spreading industrialization, the rise of developing economies, revolution in transportation technology, and the gradual opening of commodity markets.

This research can be developed in the future by studying the WTO's impact across countries and by focusing on extensive and intensive margins of trade. This kind of research will allow us to more precisely investigate the impact of the WTO on the number of varieties exported to each destination country and on the average value of exports by variety. This examination will be useful for developing resource-rich countries.

\section{Policy Implications}

After analyzing and discussing the results of our estimations, we can draw some general 
policy implications for resource-rich countries and their resource-poor partners.

Regarding natural resource-rich countries, the results of our study indicated that emerging resource-rich countries receive the maximum benefits from their accession to the WTO. In return, the WTO has no effect on non-emerging resource-rich members, which benefit more from regional integrations and bilateral agreements. This implies that the export diversification and an improvement in the competitiveness of emerging resource-rich countries inclined them toward trade liberalization; these features also helped them to benefit from the accession to the WTO. However, non-emerging resource-countries were more oriented toward the regional markets because of their lack of competitiveness. Consequently, resource-rich countries, especially non-emerging ones, will be encouraged to establish and join regional integrations to gain access to the markets of their regional partners as a first stage. This will contribute toward enhancing the productivity and improving the competitiveness of their non-natural resource sectors. Hence, in the second stage, these gains from the regional integration will improve the competitiveness of the resource-rich countries at an international level, thereby enabling them to take advantage of the benefits of trade liberalization after their accession to the WTO. Therefore, to ensure the success of this strategy, resource-rich countries must follow reform policies to improve their own governance. Owing to the efficiency of the institutions, these countries will be able to manage their savings from the export of natural resources effectively and allocate a part of these to export diversification.

For resource-poor countries, our study indicated that regional economic blocks stimulated the intra-regional exports of these countries toward their partners and increased the former's natural resource imports from the latter. Additionally, our results indicated that the accession to WTO had a positive impact on both emerging- and non-emerging- resource-poor countries. However, the competition among resource-poor countries poses challenges to these countries, especially with large emerging exporters. Therefore, resource-poor countries are called to accelerate the process of joining the regional blocs and signing bilateral agreements, especially with resource-rich countries and developed countries. Regional integration enables resource-poor countries to earn more foreign exchange, by increasing their intra-regional exports, and thus enables them to import more capital goods from the rest of the world. This will enhance their productivity and the competitiveness of their exports, and will thereby ensure that these countries, especially the non-emerging ones, can compete internationally. Additionally, these countries should improve their quality of institutions to ensure the following: signing beneficial trade agreements, improving the conditions of labor, and taking advantage of foreign exchange earnings to increase the import of capital goods. These countries must also increase investment in physical capital, which will allow them to increase productivity and competitiveness. 


\section{References}

Anderson, J. E. (1979). "A theoretical foundation for the gravity equation." The American Economic Review 69, no. 1, 106-116.

Anderson, J. E., and Van Wincoop, E. (2003). "Gravity with gravitas: a solution to the border puzzle." American economic review 93, no. 1, 170-192.

Anderson, J. E., and Yotov, Y. V. (2012). Gold standard gravity, National Bureau of Economic Research Working Paper No. w17835.

Anderson, J. E., and Yotov, Y. V. (2016). "Terms of trade and global efficiency effects of free trade agreements, 1990-2002." Journal of International Economics 99, 279-298.

Baier, S. L., and Bergstrand, J. H. (2007). 'Do free trade agreements actually increase members' international trade?" Journal of international Economics 71, no. 1, 72-95.

Baier, S. L., and Bergstrand, J. H. (2009). "Estimating the effects of free trade agreements on international trade flows using matching econometrics." Journal of international Economics 77, no. 1, 63-76.

Baier, S. L., Bergstrand, J. H., and Vidal, E. (2007). "Free trade agreements in the Americas: Are the trade effects larger than anticipated?." World Economy 30, no. 9, 1347-1377.

Baldwin, R., and Taglioni, D. (2006). Gravity for dummies and dummies for gravity equations, National Bureau of Economic Research Working Paper No. w12516.

Bayoumi, T., and Eichengreen, B. (1997). "Is Regionalism Simply a Diversion? Evidence from the Evolution of the EC and EFTA." In Regionalism versus Multilateral Trade Arrangements, NBER-EASE Volume 6 (pp. 141-168). University of Chicago Press.

Bergstrand, J. H. (1985). "The gravity equation in international trade: some microeconomic foundations and empirical evidence." The review of economics and statistics, 474-481.

Bergstrand, J. H. (1989). "The generalized gravity equation, monopolistic competition, and the factor-proportions theory in international trade." The review of economics and statistics, 143153.

Berthou, A., and Fontagne, L. (2008). The Euro and the Intensive and Extensive Margins of Trade: Evidence from French Firm Level Data. Working Papers 2008-06, CEPII research center.

Bista, R. (2015). "Reconciling the WTO effects on trade at the extensive and intensive margins." International Economic Journal 29, no. 2, 231-257.

Burger, M., Van Oort, F., and Linders, G. J. (2009). "On the specification of the gravity model of trade: zeros, excess zeros and zero-inflated estimation.” Spatial Economic Analysis 4, no. 2, 167190.

Carbaugh, R. J. (2007), International Economics (11th edition), Mason: South-Western Cengage Learning, Inc.

Carrere, C. (2006). "Revisiting the effects of regional trade agreements on trade flows with proper specification of the gravity model." European Economic Review 50, no. 2, 223-247.

Carrere, C., De Melo, J., and Wilson, J. (2013). "The Distance Puzzle and Low-Income Countries: An Update." Journal of Economic Surveys 27, no. 4, 717-742.

Carrere, C., Gourdon, J., and Olarreaga, M. (2012). Regional integration and natural resources: Who benefits? Evidence from MENA. The World Bank.

Chang, P. L., and Lee, M. J. (2011). "The WTO trade effect." Journal of International Economics 85, 
no. $1,53-71$.

Cheng, I. H., and Wall, H. J. (2005). "Controlling for heterogeneity in gravity models of trade and integration." Federal Reserve Bank of St. Louis Review 87, no. 1, 49-63.

Cheong, J., Kwak, D. W., and Tang, K. K. (2014). "The WTO puzzle, multilateral resistance terms and multicollinearity." Applied Economics Letters 21, no. 13, 928-933.

Cliff, T. (2014). Exploratory data analysis in business and economics: An introduction using SPSS. Stata, and Excel: Springer, New York, 215.

Coe, D. T., and Helpman, E. (1995). "International r\&d spillovers." European economic review 39, no. $5,859-887$.

Davis, G. A. (2010). Trade in mineral resources (No. ERSD-2010-01). WTO Staff Working Paper.

Deardorff, A. (1998). Determinants of Bilateral Trade: Does Gravity Work in a Neoclassical World?. NBER Chapters, 7-32.

Dutt, P., Mihov, I., and Van Zandt, T. (2013). "The effect of WTO on the extensive and the intensive margins of trade." Journal of international Economics 91, no. 2, 204-219.

Eaton, J., and Kortum, S. (2002). "Technology, geography, and trade." Econometrica 70, no. 5, 17411779.

Eicher, T. S., and Henn, C. (2011). "In search of WTO trade effects: Preferential trade agreements promote trade strongly, but unevenly." Journal of International Economics 83, no. 2, 137-153.

Endoh, M. (1999). "Trade creation and trade diversion in the EEC, the LAFTA and the CMEA: 1960-1994." Applied Economics 31, no. 2, 207-216.

Engelbrecht, H. J., and Pearce, C. (2007). "The GATT/WTO has promoted trade, but only in capital-intensive commodities!." Applied Economics 39, no. 12, 1573-1581.

Evenett, S. J., and Keller, W. (2002). "On theories explaining the success of the gravity equation." Journal of political economy 110, no. 2, 281-316.

Fally, T. (2015). "Structural gravity and fixed effects." Journal of International Economics 97, no. 1, 76-85.

Feenstra, R., (2004). Advanced International Trade: Theory and Evidence. Princeton University Press, Princeton, N.J.

Felbermayr, G. J., and Kohler, W. (2006). "Exploring the intensive and extensive margins of world trade." Review of World Economics 142, no. 4, 642-674.

Felbermayr, G., and Kohler, W. (2010). "Modelling the extensive margin of world trade: new evidence on GATT and WTO membership." The World Economy 33, no. 11, 1430-1469.

Filippini, C., and Molini, V. (2003). "The determinants of East Asian trade flows: a gravity equation approach." Journal of asian Economics 14, no. 5, 695-711.

Fouquin, M., Langhammer, R. O. L. F., and Schweickert, R. (2006, April). "Natural Resource Abundance and its Impact on Regional Integration. Curse or Blessing?." In ELSNIT/Fundacao Getulio Vargas Conference in Sao Paulo.

Gil, S., Llorca, R., and Martinez-Serrano, J. A. (2008a). "Assessing the enlargement and deepening of the European Union." World Economy 31, no. 9, 1253-1272.

Gil-Pareja, S., Llorca-Vivero, R., and Martinez-Serrano, J. A. (2008b). "Trade effects of monetary agreements: evidence for OECD countries.” European Economic Review 52, no. 4, 733-755. 
Glick, R., and Rose, A. K. (2002). "Does a currency union affect trade? The time-series evidence." European Economic Review 46, no. 6, 1125-1151.

Grant, J. H., and Boys, K. A. (2011). "Agricultural trade and the GATT/WTO: does membership make a difference?." American Journal of Agricultural Economics 94, no. 1, 1-24.

Head, K., and Mayer, T. (2014). "Gravity equations: Workhorse, toolkit, and cookbook." In Handbook of international economics (Vol. 4, pp. 131-195). Elsevier.

Helpman, E., and Krugman, P. R. (1985). Market structure and foreign trade: Increasing returns, imperfect competition, and the international economy. MIT press.

Helpman, E., Melitz, M., and Rubinstein, Y. (2008). "Estimating trade flows: Trading partners and trading volumes." The quarterly journal of economics 123, no. 2, 441-487.

Herz, B., and Wagner, M. (2011b). "The dark side of the generalized system of preferences." Review of International Economics 19, no. 4, 763-775.

Herzl, B., and Wagner, M. (2011a). "The "Real” Impact of GATT/WTO-A Generalized Approach.“ World Economy 34, no. 6, 1014-1041.

International Monetary Fund. (2012). Macroeconomic policy frameworks for resource-rich developing countries. International Monetary Fund. Washington, DC.

International Monetary Fund. (2015). World Economic Outlook: Adjusting to Lower Commodity Prices. Washington.

International Monetary Fund. Fiscal Affairs Dept. (2007). Guide on Resource Revenue Transparency. International Monetary Fund. Washington, DC.

Kim, M. H. (2010). "Does the WTO promote trade? Further evidence." The Journal of International Trade \& Economic Development 19, no. 3, 421-437.

Kohl, T. (2017). "The WTO's effect on trade: What you give is what you get." In Globalization (pp. 459-493). Springer, Berlin, Heidelberg.

Kohl, T., and Trojanowska, S. (2015). "Heterogeneous trade agreements, WTO membership and international trade: an analysis using matching econometrics." Applied Economics 47, no. 33, 3499-3509.

Krugman, P. (1991). "The move toward free trade zones." Economic Review 76, no. 6, 5.

Larch, M., Wanner, J., Yotov, Y., and Zylkin, T. (2017). The currency union effect: A PPML reassessment with high-dimensional fixed effects.

Lee, J. W., and Swagel, P. (1997). "Trade barriers and trade flows across countries and industries." Review of Economics and Statistics 79, no. 3, 372-382.

Lee, J. W., Park, I., and Shin, K. (2008). "Proliferating regional trade arrangements: Why and whither?." World Economy 31, no. 12, 1525-1557.

Liu, X. (2009). "GATT/WTO promotes trade strongly: Sample selection and model specification." Review of international Economics 17, no. 3, 428-446.

Magee, C. S. (2003). "Endogenous preferential trade agreements: An empirical analysis." Contributions in Economic Analysis \& Policy 2, no. 1.

Magee, C. S. (2008). "New measures of trade creation and trade diversion." Journal of International Economics 75, no. 2, 349-362.

Martin, W., and Pham, C. S. (2015). Estimating the gravity model when zero trade flows are frequent 
and economically determined. The World Bank.

Martinez-Zarzoso, I., Felicitas, N. L. D., and Horsewood, N. (2009). "Are regional trading agreements beneficial?: Static and dynamic panel gravity models." The North American Journal of Economics and Finance 20, no. 1, 46-65.

Mattoo, A., Roy, D., and Subramanian, A. (2003). "The Africa Growth and Opportunity Act and its Rules of Origin: Generosity Undermined?." World Economy 26, no. 6, 829-851.

Micco, A., Stein, E., and Ordonez, G. (2003). "The currency union effect on trade: early evidence from EMU." Economic policy 18, no. 37 315-356.

Mujahid, I., and Kalkuhl, M. (2016). "Do Trade Agreements Increase Food Trade?." The World Economy 39, no. 11, 1812-1833.

Rose, A. K. (2000). "One money, one market: the effect of common currencies on trade." Economic policy 15 , no. 30, 08-45.

Rose, A. K. (2004). "Do we really know that the WTO increases trade?." American Economic Review 94, no. 1, 98-114.

Rose, A. K. (2004). "Do we really know that the WTO increases trade?." American Economic Review 94, no. $1,98-114$.

Roy, J. (2011). "Is the WTO mystery really solved?." Economics Letters 113, no. 2, 127-130.

Silva, J. M. S., Tenreyro, S., and Windmeijer, F. (2015). "Testing competing models for nonnegative data with many zeros." Journal of Econometric Methods 4, no. 1, 29-46.

Silva, J. S., and Tenreyro, S. (2006). "The log of gravity." The Review of Economics and statistics 88, no. 4, 641-658.

Silva, J. S., and Tenreyro, S. (2010). "On the existence of the maximum likelihood estimates in Poisson regression.” Economics Letters 107, no. 2, 310-312.

Soloaga, I., and Winters, L. A. (2001). "Regionalism in the nineties: What effect on trade?." The North American Journal of Economics and Finance 12, no. 1, 1-29.

Subramanian, A., and Wei, S. J. (2007). "The WTO promotes trade, strongly but unevenly." Journal of international Economics 72, no. 1, 151-175.

Tinbergen, J. (1962). Shaping the world economy: suggestions for an international trade policy. Twentieth Century Fund Press, New York.

Tomz, M., Goldstein, J. L., and Rivers, D. (2007). "Do we really know that the WTO increases trade? Comment." American Economic Review 97, no. 5, 2005-2018.

Tomz, M., Goldstein, J. L., and Rivers, D. (2007). "Do we really know that the WTO increases trade? Comment." American Economic Review 97, no. 5, 2005-2018.

Trefler, D. (1993). "Trade liberalization and the theory of endogenous protection: an econometric study of US import policy." Journal of political Economy 101, no. 1, 138-160.

Trefler, D. (1995). "The case of the missing trade and other mysteries." The American Economic Review 1029-1046.

Trefler, D. (2004). "The long and short of the Canada-US free trade agreement." American Economic Review 94, no. 4, 870-895.

Trotignon, J. (2010). "Does regional integration promote the multilateralization of trade flows? A gravity 
model using panel data." Journal of Economic Integration 223-251.

Venables, A. (2009), "Economic integration in remote resource rich regions." OxCarre, Working Paper.

Venables, A. (2011). "Economic integration in remote resource-rich regions (pp. 187-207)." Oxford: Oxford University Press.

Viner, J. (1950), The Customs Union Issue, New York: Carnegie Endowment for International Peace.

Westerlund, J., and Wilhelmsson, F. (2011). "Estimating the gravity model without gravity using panel data." Applied Economics 43, no. 6, 641-649.

World Bank. (2008): Middle East and North Africa Economic Developments and Prospects, 2008 : Regional Integration for Global Competitiveness. World Bank. Washington, DC.

World Trade Report. (2010). Trade in natural resources. World Trade Organization: Geneva.

Yotov, Y. V., Piermartini, R., Monteiro, J. A., and Larch, M. (2016). An advanced guide to trade policy analysis: The structural gravity model. Geneva: World Trade Organization.

United Nations Conference on Trade and Development (UNCTAD) website: https:/unctad.org/en/Pages/sta tistics.aspx

World Trade Organization (WTO) website: https://www.wto.org/

World Integrated Trade Solutions (WITS): http://wits.worldbank.org

Regional Trade Agreements Information System (RTA-IS): http://rtais.wto.org/UI/PublicMaintainRTAHome.aspx

Mario Larch's Regional Trade Agreements Database: http://www.ewf.uni-bayreuth.de/en/research/RTA-dat a/index.html

CEPII Gravity Dataset: http://www.cepii.fr/CEPII/en/bdd_modele/download.asp?id=8

Investopedia website: https://www.investopedia.com/terms/e/emergingmarketeconomy.asp 


\section{Appendix 1. List of 200 countries and several natural resource endowments indicators over the period from 1995 2015 in average}

\begin{tabular}{|c|c|c|c|c|c|c|}
\hline Country & $\begin{array}{l}\text { Share of natural } \\
\text { resources in total } \\
\text { exports (\%) }\end{array}$ & $\begin{array}{l}\text { Ratio of natural } \\
\text { resource exports } \\
\text { in GDP (\%) }\end{array}$ & $\begin{array}{l}\text { Share of natural } \\
\text { resource sectors } \\
\text { in GDP (\%) }\end{array}$ & $\begin{array}{c}\text { Agriculture, } \\
\text { hunting, forestry, } \\
\text { fishing (\%) }\end{array}$ & $\begin{array}{c}\text { Mining } \\
(\%)\end{array}$ & $\begin{array}{l}\text { Concentration } \\
\text { Index }\end{array}$ \\
\hline Afghanistan & 34,81 & 1,32 & 41,79 & 41,30 & 0,50 & 0,30 \\
\hline Albania & 24,82 & 2,91 & 31,79 & 26,07 & 5,71 & 0,24 \\
\hline Algeria & 97,19 & 32,97 & 46,40 & 9,65 & 36,75 & 0,53 \\
\hline Andorra & 4,73 & 0,16 & 1,98 & 0,50 & 1,49 & 0,20 \\
\hline Angola & 99,69 & 55,08 & 53,36 & 6,85 & 46,51 & 0,92 \\
\hline Anguilla & 4,30 & 0,14 & 7,12 & 2,47 & 4,64 & 0,31 \\
\hline $\begin{array}{c}\text { Antigua and } \\
\text { Barbuda }\end{array}$ & 16,19 & 1,04 & 6,14 & 1,90 & 4,25 & 0,49 \\
\hline Argentina & 19,97 & 2,87 & 13,30 & 7,20 & 6,10 & 0,15 \\
\hline Armenia & 51,35 & 7,39 & 30,51 & 23,69 & 6,82 & 0,25 \\
\hline Aruba & 86,39 & 97,08 & 7,33 & 0,44 & 6,89 & 0,76 \\
\hline Australia & 60,25 & 9,14 & 12,38 & 2,99 & 9,39 & 0,18 \\
\hline Austria & 7,94 & 2,78 & 5,52 & 1,68 & 3,84 & 0,07 \\
\hline Azerbaijan & 86,44 & 35,36 & 49,26 & 12,31 & 36,95 & 0,69 \\
\hline Bahamas & 38,93 & 2,46 & 4,93 & 1,33 & 3,60 & 0,40 \\
\hline Bahrain & 69,52 & 42,14 & 22,75 & 0,47 & 22,28 & 0,38 \\
\hline Bangladesh & 6,76 & 0,96 & 23,57 & 20,91 & 2,66 & 0,39 \\
\hline Barbados & 25,46 & 2,48 & 4,78 & 2,04 & 2,74 & 0,21 \\
\hline Belarus & 28,73 & 15,04 & 16,02 & 11,09 & 4,93 & 0,23 \\
\hline Belgium & 16,26 & 13,48 & 3,96 & 1,05 & 2,91 & 0,10 \\
\hline Belize & 29,10 & 8,99 & 19,08 & 14,93 & 4,15 & 0,28 \\
\hline Benin & 67,03 & 11,43 & 26,74 & 25,61 & 1,13 & 0,46 \\
\hline Bermuda & 14,76 & 0,09 & 2,59 & 0,74 & 1,84 & 0,56 \\
\hline Bhutan & 30,79 & 10,55 & 39,43 & 23,46 & 15,98 & 0,33 \\
\hline Bolivia & 64,39 & 18,70 & 28,49 & 13,81 & 14,68 & 0,33 \\
\hline $\begin{array}{l}\text { Bosnia and } \\
\text { Herzegovina }\end{array}$ & 34,35 & 7,24 & 20,40 & 11,70 & 8,70 & 0,14 \\
\hline Botswana & 84,98 & 37,81 & 33,16 & 2,95 & 30,21 & 0,71 \\
\hline Brazil & 22,84 & 2,28 & 10,82 & 5,45 & 5,37 & 0,11 \\
\hline Brunei Darussalam & 92,45 & 52,84 & 46,70 & 0,92 & 45,78 & 0,63 \\
\hline Bulgaria & 26,30 & 11,07 & 16,41 & 9,47 & 6,94 & 0,11 \\
\hline Burkina Faso & 74,61 & 9,49 & 39,85 & 35,52 & 4,34 & 0,61 \\
\hline Burundi & 25,19 & 1,30 & 43,73 & 42,50 & 1,23 & 0,58 \\
\hline Cabo Verde & 40,50 & 0,99 & 17,38 & 11,86 & 5,52 & 0,34 \\
\hline Cambodia & 13,34 & 4,18 & 37,82 & 36,80 & 1,02 & 0,34 \\
\hline
\end{tabular}




\section{Appendix 1. Continued}

\begin{tabular}{|c|c|c|c|c|c|c|}
\hline Country & $\begin{array}{l}\text { Share of natural } \\
\text { resources in total } \\
\text { exports (\%) }\end{array}$ & $\begin{array}{l}\text { Ratio of natural } \\
\text { resource exports } \\
\text { in GDP (\%) }\end{array}$ & $\begin{array}{l}\text { Share of natural } \\
\text { resource sectors } \\
\text { in GDP }(\%)\end{array}$ & $\begin{array}{l}\text { Agriculture, } \\
\text { hunting, forestry, } \\
\text { fishing (\%) }\end{array}$ & $\begin{array}{c}\text { Mining } \\
(\%)\end{array}$ & $\begin{array}{l}\text { Concentration } \\
\text { Index }\end{array}$ \\
\hline Cameroon & 71,29 & 11,48 & 24,25 & 15,85 & 8,40 & 0,39 \\
\hline Canada & 32,64 & 9,49 & 11,48 & 2,03 & 9,45 & 0,14 \\
\hline $\begin{array}{l}\text { Central African } \\
\text { Republic }\end{array}$ & 87,19 & 9,20 & 45,82 & 41,21 & 4,61 & 0,47 \\
\hline Chad & 94,45 & 25,40 & 42,91 & 29,34 & 13,58 & 0,81 \\
\hline Chile & 69,41 & 19,79 & 19,59 & 4,74 & 14,84 & 0,32 \\
\hline China & 6,17 & 1,45 & 34,75 & 12,91 & 21,84 & 0,09 \\
\hline Hong Kong & 8,13 & 13,02 & 2,56 & 0,09 & 2,47 & 0,15 \\
\hline Macao & 3,87 & 0,36 & 1,82 & - & 1,82 & 0,30 \\
\hline Taiwan & 7,62 & 4,08 & 4,44 & 1,99 & 2,45 & 0,17 \\
\hline Colombia & 54,36 & 7,35 & 18,70 & 7,94 & 10,77 & 0,29 \\
\hline Comoros & 4,84 & 0,07 & 39,54 & 37,55 & 1,99 & 0,62 \\
\hline Congo & 93,16 & 66,66 & 65,55 & 6,23 & 59,32 & 0,75 \\
\hline Cook Islands & 56,53 & 2,27 & 9,78 & 7,47 & 2,31 & 0,50 \\
\hline Costa Rica & 5,73 & 1,80 & 12,84 & 9,29 & 3,54 & 0,31 \\
\hline Cote d'Ivoire & 34,94 & 13,61 & 30,64 & 25,42 & 5,22 & 0,35 \\
\hline Croatia & 20,55 & 4,17 & 11,36 & 5,52 & 5,84 & 0,11 \\
\hline Cuba & 27,71 & 1,63 & 7,75 & 5,07 & 2,67 & 0,33 \\
\hline Cyprus & 17,02 & 1,32 & 5,66 & 3,31 & 2,36 & 0,24 \\
\hline Czechia & 7,34 & 4,07 & 8,86 & 2,82 & 6,04 & 0,09 \\
\hline $\begin{array}{l}\text { Dem. Rep. } \\
\text { of the Congo }\end{array}$ & 92,74 & 16,06 & 43,85 & 29,84 & 14,01 & 0,48 \\
\hline Denmark & 14,34 & 4,36 & 7,16 & 1,92 & 5,23 & 0,08 \\
\hline Djibouti & 27,89 & 1,87 & 8,98 & 3,52 & 5,46 & 0,22 \\
\hline Dominica & 5,97 & 0,59 & 19,47 & 13,75 & 5,72 & 0,42 \\
\hline $\begin{array}{c}\text { Dominican } \\
\text { Republic }\end{array}$ & 6,96 & 1,11 & 10,97 & 7,45 & 3,52 & 0,20 \\
\hline Ecuador & 67,69 & 15,62 & 21,93 & 13,05 & 8,88 & 0,45 \\
\hline Egypt & 47,28 & 4,45 & 27,38 & 13,47 & 13,92 & 0,22 \\
\hline El Salvador & 6,50 & 1,35 & 13,45 & 11,16 & 2,30 & 0,22 \\
\hline Equatorial Guinea & 93,98 & 67,20 & 55,74 & 3,19 & 52,55 & 0,75 \\
\hline Eritrea & 43,65 & 3,62 & 19,84 & 18,41 & 1,44 & 0,34 \\
\hline Estonia & 21,67 & 13,01 & 9,18 & 4,02 & 5,16 & 0,13 \\
\hline Ethiopia & 22,57 & 1,44 & 48,92 & 46,61 & 2,31 & 0,41 \\
\hline Fiji & 33,75 & 9,24 & 15,33 & 13,11 & 2,22 & 0,25 \\
\hline Finland & 15,99 & 4,87 & 6,18 & 3,01 & 3,17 & 0,18 \\
\hline France & 7,10 & 1,40 & 4,68 & 2,06 & 2,62 & 0,08 \\
\hline Gabon & 94,79 & 48,72 & 52,28 & 5,39 & 46,89 & 0,76 \\
\hline Gambia & 40,99 & 1,90 & 26,74 & 23,92 & 2,82 & 0,35 \\
\hline
\end{tabular}




\section{Appendix 1. Continued}

\begin{tabular}{|c|c|c|c|c|c|c|}
\hline Country & $\begin{array}{l}\text { Share of natural } \\
\text { resources in total } \\
\text { exports }(\%)\end{array}$ & $\begin{array}{l}\text { Ratio of natural } \\
\text { resource exports } \\
\text { in GDP (\%) }\end{array}$ & $\begin{array}{l}\text { Share of natural } \\
\text { resource sectors } \\
\text { in GDP (\%) }\end{array}$ & $\begin{array}{l}\text { Agriculture, } \\
\text { hunting, forestry, } \\
\text { fishing (\%) }\end{array}$ & $\begin{array}{c}\text { Mining } \\
(\%)\end{array}$ & $\begin{array}{l}\text { Concentration } \\
\text { Index }\end{array}$ \\
\hline Georgia & 28,69 & 3,19 & 21,87 & 17,83 & 4,04 & 0,19 \\
\hline Germany & 5,77 & 1,91 & 4,82 & 1,07 & 3,75 & 0,10 \\
\hline Ghana & 50,62 & 11,07 & 34,82 & 29,28 & 5,54 & 0,40 \\
\hline Greece & 30,90 & 3,12 & 8,57 & 4,92 & 3,65 & 0,16 \\
\hline Greenland & 91,06 & 21,01 & 13,49 & 10,46 & 3,04 & 0,47 \\
\hline Grenada & 15,53 & 0,80 & 10,94 & 6,14 & 4,79 & 0,25 \\
\hline Guatemala & 12,26 & 2,28 & 19,69 & 15,86 & 3,83 & 0,17 \\
\hline Guinea & 89,59 & 16,00 & 35,32 & 19,83 & 15,49 & 0,55 \\
\hline Guinea-Bissau & 25,77 & 3,11 & 46,00 & 45,23 & 0,77 & 0,74 \\
\hline Guyana & 57,16 & 24,50 & 42,36 & 25,09 & 17,26 & 0,37 \\
\hline Haiti & 3,25 & 0,29 & 22,06 & 21,18 & 0,88 & 0,45 \\
\hline Honduras & 13,89 & 6,06 & 17,22 & 14,45 & 2,77 & 0,26 \\
\hline Hungary & 5,67 & 3,25 & 9,05 & 5,18 & 3,88 & 0,12 \\
\hline Iceland & 76,14 & 20,06 & 12,29 & 7,62 & 4,67 & 0,40 \\
\hline India & 30,51 & 3,76 & 27,48 & 21,49 & 5,99 & 0,15 \\
\hline Indonesia & 41,87 & 10,30 & 24,69 & 13,84 & 10,86 & 0,14 \\
\hline Iran & 80,61 & 16,47 & 28,64 & 8,22 & 20,42 & 0,69 \\
\hline Iraq & 97,74 & 55,45 & 66,40 & 6,66 & 59,74 & 0,94 \\
\hline Ireland & 2,82 & 1,57 & 4,78 & 2,17 & 2,62 & 0,22 \\
\hline Israel & 33,87 & 8,25 & 3,69 & 1,62 & 2,07 & 0,30 \\
\hline Italy & 5,94 & 1,29 & 5,43 & 2,51 & 2,92 & 0,05 \\
\hline Jamaica & 64,87 & 8,92 & 12,74 & 6,59 & 6,15 & 0,52 \\
\hline Japan & 4,34 & 0,55 & 4,22 & 1,29 & 2,93 & 0,13 \\
\hline Jordan & 15,72 & 4,26 & 8,82 & 3,01 & 5,81 & 0,18 \\
\hline Kazakhstan & 76,57 & 30,07 & 24,63 & 7,53 & 17,10 & 0,51 \\
\hline Kenya & 26,04 & 3,33 & 29,65 & 26,42 & 3,23 & 0,22 \\
\hline Kiribati & 62,27 & 3,46 & 25,45 & 24,22 & 1,23 & 0,60 \\
\hline $\begin{array}{l}\text { Korea, Dem. } \\
\text { People's Rep. of }\end{array}$ & 37,51 & 6,16 & 40,01 & 25,56 & 14,46 & 0,20 \\
\hline Korea, Republic of & 10,50 & 3,69 & 6,24 & 3,50 & 2,74 & 0,15 \\
\hline Kuwait & 90,41 & 46,90 & 47,87 & 0,37 & 47,51 & 0,64 \\
\hline Kyrgyzstan & 49,76 & 15,28 & 34,30 & 30,36 & 3,94 & 0,27 \\
\hline $\begin{array}{l}\text { Lao People's } \\
\text { Dem. Rep. }\end{array}$ & 52,85 & 10,15 & 41,87 & 30,01 & 11,85 & 0,30 \\
\hline Latvia & 29,09 & 8,56 & 8,99 & 4,67 & 4,32 & 0,13 \\
\hline Lebanon & 23,18 & 2,30 & 13,74 & 4,47 & 9,27 & 0,12 \\
\hline Lesotho & 13,36 & 5,01 & 15,94 & 6,79 & 9,15 & 0,33 \\
\hline Liberia & 43,88 & 34,80 & 73,77 & 72,11 & 1,66 & 0,59 \\
\hline
\end{tabular}




\section{Appendix 1. Continued}

\begin{tabular}{|c|c|c|c|c|c|c|}
\hline Country & $\begin{array}{l}\text { Share of natural } \\
\text { resources in total } \\
\text { exports (\%) }\end{array}$ & $\begin{array}{l}\text { Ratio of natural } \\
\text { resource exports } \\
\text { in GDP (\%) }\end{array}$ & $\begin{array}{l}\text { Share of natural } \\
\text { resource sectors } \\
\text { in GDP (\%) }\end{array}$ & $\begin{array}{l}\text { Agriculture, } \\
\text { hunting, forestry, } \\
\text { fishing (\%) }\end{array}$ & $\begin{array}{c}\text { Mining } \\
(\%)\end{array}$ & $\begin{array}{l}\text { Concentration } \\
\text { Index }\end{array}$ \\
\hline Libya & 95,04 & 46,54 & 53,91 & 3,75 & 50,16 & 0,78 \\
\hline Lithuania & 27,24 & 12,82 & 10,29 & 5,68 & 4,62 & 0,16 \\
\hline Luxembourg & 8,25 & 3,16 & 2,34 & 0,55 & 1,80 & 0,13 \\
\hline Madagascar & 32,37 & 4,60 & 34,30 & 32,60 & 1,70 & 0,24 \\
\hline Malawi & 5,36 & 0,93 & 36,41 & 34,29 & 2,11 & 0,56 \\
\hline Malaysia & 18,23 & 15,34 & 22,59 & 9,78 & 12,81 & 0,19 \\
\hline Maldives & 71,77 & 8,25 & 8,42 & 6,56 & 1,85 & 0,53 \\
\hline Mali & 85,93 & 16,01 & 37,72 & 36,08 & 1,64 & 0,67 \\
\hline Malta & 19,74 & 7,78 & 3,38 & 2,11 & 1,26 & 0,43 \\
\hline Marshall Islands & 28,43 & 4,87 & 15,31 & 12,01 & 3,30 & 0,71 \\
\hline Mauritania & 92,64 & 31,19 & 48,36 & 29,97 & 18,40 & 0,49 \\
\hline Mauritius & 12,53 & 3,32 & 8,02 & 5,84 & 2,18 & 0,30 \\
\hline Mexico & 15,62 & 4,03 & 12,40 & 3,63 & 8,77 & 0,14 \\
\hline Micronesia & 59,19 & 6,08 & 27,98 & 25,86 & 2,12 & 0,61 \\
\hline Mongolia & 82,94 & 30,79 & 39,13 & 20,00 & 19,13 & 0,42 \\
\hline Montenegro & 34,85 & 4,02 & 19,99 & 13,61 & 6,38 & 0,19 \\
\hline Montserrat & 24,14 & 1,02 & 4,45 & 1,46 & 2,99 & 0,31 \\
\hline Morocco & 24,23 & 4,54 & 19,60 & 14,78 & 4,82 & 0,17 \\
\hline Mozambique & 71,05 & 13,65 & 31,43 & 27,40 & 4,03 & 0,40 \\
\hline Myanmar & 58,75 & 12,80 & 48,41 & 45,83 & 2,58 & 0,32 \\
\hline Namibia & 63,25 & 21,33 & 23,31 & 9,47 & 13,84 & 0,28 \\
\hline Nauru & 70,39 & 58,26 & 22,83 & 5,62 & 17,22 & 0,63 \\
\hline Nepal & 5,73 & 0,45 & 37,74 & 35,58 & 2,16 & 0,20 \\
\hline Netherlands & 18,11 & 11,31 & 6,84 & 2,24 & 4,60 & 0,10 \\
\hline New Zealand & 24,40 & 5,18 & 11,11 & 6,43 & 4,67 & 0,14 \\
\hline Nicaragua & 17,47 & 4,33 & 22,59 & 19,19 & 3,40 & 0,21 \\
\hline Niger & 48,11 & 7,78 & 48,52 & 42,10 & 6,42 & 0,39 \\
\hline Nigeria & 95,99 & 22,75 & 39,87 & 25,70 & 14,17 & 0,85 \\
\hline Niue & 14,26 & - & 0,00 & - & 0,00 & 0,34 \\
\hline Norway & 74,54 & 23,24 & 26,18 & 1,82 & 24,36 & 0,40 \\
\hline Oman & 82,05 & 46,05 & 46,56 & 1,86 & 44,70 & 0,65 \\
\hline Pakistan & 7,12 & 0,84 & 30,92 & 25,97 & 4,95 & 0,21 \\
\hline Palau & 74,60 & 4,34 & 7,44 & 4,68 & 2,77 & 0,71 \\
\hline Panama & 17,27 & 3,49 & 9,61 & 5,68 & 3,93 & 0,19 \\
\hline Papua New Guinea & 77,66 & 30,27 & 41,59 & 21,73 & 19,86 & 0,33 \\
\hline Paraguay & 33,49 & 10,94 & 29,83 & 20,01 & 9,82 & 0,39 \\
\hline Peru & 67,92 & 12,88 & 20,35 & 8,09 & 12,26 & 0,24 \\
\hline Philippines & 8,30 & 2,39 & 18,14 & 13,48 & 4,66 & 0,34 \\
\hline
\end{tabular}




\section{Appendix 1. Continued}

\begin{tabular}{|c|c|c|c|c|c|c|}
\hline Country & $\begin{array}{l}\text { Share of natural } \\
\text { resources in total } \\
\text { exports (\%) }\end{array}$ & $\begin{array}{l}\text { Ratio of natural } \\
\text { resource exports } \\
\text { in GDP (\%) }\end{array}$ & $\begin{array}{c}\text { Share of natural } \\
\text { resource sectors } \\
\text { in GDP (\%) }\end{array}$ & $\begin{array}{l}\text { Agriculture, } \\
\text { hunting, forestry, } \\
\text { fishing (\%) }\end{array}$ & $\begin{array}{c}\text { Mining } \\
(\%)\end{array}$ & $\begin{array}{l}\text { Concentration } \\
\text { Index }\end{array}$ \\
\hline Poland & 11,90 & 3,10 & 10,18 & 3,49 & 6,69 & 0,08 \\
\hline Portugal & 11,56 & 2,60 & 6,55 & 3,06 & 3,49 & 0,10 \\
\hline Qatar & 87,80 & 50,87 & 51,25 & 0,31 & 50,94 & 0,57 \\
\hline Moldova & 4,77 & 1,64 & 23,43 & 19,84 & 3,59 & 0,20 \\
\hline Romania & 13,91 & 3,80 & 16,19 & 10,65 & 5,54 & 0,11 \\
\hline Russia & 68,73 & 19,06 & 17,24 & 5,33 & 11,92 & 0,32 \\
\hline Rwanda & 44,41 & 2,43 & 39,67 & 37,02 & 2,65 & 0,47 \\
\hline St Kitts and Nevis & 1,71 & 0,12 & 3,62 & 1,96 & 1,66 & 0,37 \\
\hline St Lucia & 25,50 & 2,82 & 8,63 & 4,35 & 4,28 & 0,43 \\
\hline $\begin{array}{l}\text { St Vincent and } \\
\text { the Grenadines }\end{array}$ & 7,46 & 0,81 & 12,11 & 7,52 & 4,59 & 0,50 \\
\hline Samoa & 13,55 & 2,01 & 17,56 & 13,42 & 4,13 & 0,52 \\
\hline $\begin{array}{l}\text { Sao Tome } \\
\text { and Principe }\end{array}$ & 10,32 & 0,46 & 20,27 & 17,74 & 2,53 & 0,52 \\
\hline Saudi Arabia & 82,04 & 36,23 & 43,61 & 3,80 & 39,81 & 0,68 \\
\hline Senegal & 54,43 & 9,83 & 21,38 & 17,04 & 4,33 & 0,24 \\
\hline Serbia & 16,98 & 2,68 & 19,68 & 13,89 & 5,79 & 0,10 \\
\hline Seychelles & 84,94 & 27,67 & 5,90 & 3,83 & 2,07 & 0,52 \\
\hline Sierra Leone & 54,81 & 6,47 & 57,09 & 51,43 & 5,66 & 0,40 \\
\hline Singapore & 14,70 & 21,72 & 1,82 & 0,07 & 1,74 & 0,25 \\
\hline Slovakia & 10,19 & 6,43 & 9,87 & 4,25 & 5,63 & 0,14 \\
\hline Slovenia & 8,04 & 4,46 & 6,65 & 2,76 & 3,89 & 0,13 \\
\hline Solomon Islands & 83,94 & 26,88 & 34,99 & 32,27 & 2,72 & 0,60 \\
\hline Somalia & 27,12 & 5,16 & 60,82 & 60,15 & 0,67 & 0,55 \\
\hline South Africa & 44,32 & 9,37 & 13,58 & 3,10 & 10,48 & 0,13 \\
\hline Spain & 9,95 & 1,86 & 6,76 & 3,35 & 3,41 & 0,11 \\
\hline Sri Lanka & 10,70 & 2,15 & 14,80 & 11,16 & 3,64 & 0,22 \\
\hline State of Palestine & 8,10 & 0,60 & 12,27 & 8,24 & 4,04 & 0,17 \\
\hline Sudan & 77,17 & 8,70 & 44,45 & 36,04 & 8,41 & 0,55 \\
\hline Suriname & 71,11 & 29,86 & 23,49 & 15,39 & 8,10 & 0,50 \\
\hline Swaziland & 14,06 & 7,23 & 12,52 & 10,40 & 2,12 & 0,25 \\
\hline Sweden & 13,91 & 4,39 & 5,32 & 1,78 & 3,54 & 0,11 \\
\hline Switzerland & 12,11 & 4,70 & 3,50 & 1,01 & 2,49 & 0,16 \\
\hline Syria & 57,33 & 13,56 & 44,14 & 23,01 & 21,13 & 0,42 \\
\hline Tajikistan & 77,94 & 33,08 & 25,65 & 25,65 & 0,00 & 0,49 \\
\hline Macedonia & 12,13 & 4,10 & 18,63 & 11,96 & 6,67 & 0,17 \\
\hline Thailand & 16,58 & 8,67 & 15,23 & 9,65 & 5,58 & 0,09 \\
\hline Togo & 50,39 & 13,14 & 36,67 & 31,79 & 4,89 & 0,27 \\
\hline Tonga & 30,55 & 1,24 & 23,66 & 20,61 & 3,05 & 0,39 \\
\hline
\end{tabular}




\section{Appendix 1. Continued}

\begin{tabular}{|c|c|c|c|c|c|c|}
\hline Country & $\begin{array}{l}\text { Share of natural } \\
\text { resources in } \\
\text { total exports (\%) }\end{array}$ & $\begin{array}{l}\text { Ratio of natural } \\
\text { resource exports } \\
\text { in GDP (\%) }\end{array}$ & $\begin{array}{l}\text { Share of natural } \\
\text { resource sectors } \\
\text { in GDP (\%) }\end{array}$ & $\begin{array}{l}\text { Agriculture, } \\
\text { hunting, forestry, } \\
\text { fishing (\%) }\end{array}$ & $\begin{array}{c}\text { Mining } \\
(\%)\end{array}$ & $\begin{array}{l}\text { Concentration } \\
\text { Index }\end{array}$ \\
\hline $\begin{array}{l}\text { Trinidad and } \\
\text { Tobago }\end{array}$ & 59,51 & 31,40 & 23,84 & 0,85 & 22,99 & 0,35 \\
\hline Tunisia & 15,09 & 5,01 & 17,04 & 10,15 & 6,90 & 0,18 \\
\hline Turkey & 8,56 & 1,28 & 13,64 & 10,20 & 3,44 & 0,09 \\
\hline Turkmenistan & 89,88 & 38,06 & 19,76 & 17,71 & 2,05 & 0,63 \\
\hline $\begin{array}{c}\text { Turks and } \\
\text { Caicos Islands }\end{array}$ & 47,77 & 1,23 & 5,98 & 1,01 & 4,97 & 0,35 \\
\hline Tuvalu & 21,34 & 0,13 & 23,89 & 23,03 & 0,87 & 0,39 \\
\hline Uganda & 26,15 & 1,96 & 35,29 & 29,57 & 5,72 & 0,34 \\
\hline Ukraine & 16,65 & 6,25 & 19,91 & 11,52 & 8,39 & 0,13 \\
\hline $\begin{array}{l}\text { United Arab } \\
\text { Emirates }\end{array}$ & 71,05 & 44,73 & 32,83 & 1,31 & 31,52 & 0,43 \\
\hline United Kingdom & 16,66 & 2,84 & 5,23 & 0,83 & 4,40 & 0,10 \\
\hline $\begin{array}{c}\text { United Republic } \\
\text { of Tanzania }\end{array}$ & 52,82 & 4,81 & 36,28 & 31,56 & 4,73 & 0,26 \\
\hline United States & 11,67 & 0,95 & 4,79 & 1,08 & 3,71 & 0,08 \\
\hline Uruguay & 17,86 & 2,71 & 11,60 & 8,45 & 3,15 & 0,19 \\
\hline Uzbekistan & 62,15 & 16,60 & 30,34 & 26,68 & 3,66 & 0,35 \\
\hline Vanuatu & 41,28 & 3,61 & 27,89 & 25,88 & 2,01 & 0,50 \\
\hline Venezuela & 86,91 & 22,28 & 27,65 & 4,83 & 22,82 & 0,63 \\
\hline Viet Nam & 28,94 & 15,09 & 33,75 & 21,17 & 12,58 & 0,19 \\
\hline Yemen & 94,44 & 25,39 & 38,08 & 13,05 & 25,03 & 0,76 \\
\hline Zambia & 76,53 & 22,25 & 28,04 & 13,49 & 14,55 & 0,58 \\
\hline Zimbabwe & 39,05 & 10,71 & 29,84 & 18,22 & 11,63 & 0,27 \\
\hline
\end{tabular}

(Note) Resource Exports: Sum of Agricultural raw materials, Minerals, Fuels and Fish, where: SITC Codes of Agricultural raw materials: $(2-22+27+28)$, SITC Codes of Minerals: $(27+28+68+667+971)$, SITC Codes of Fuels: (3), SITC Codes of Fish: (03)

(Source) UNCTAD 
产

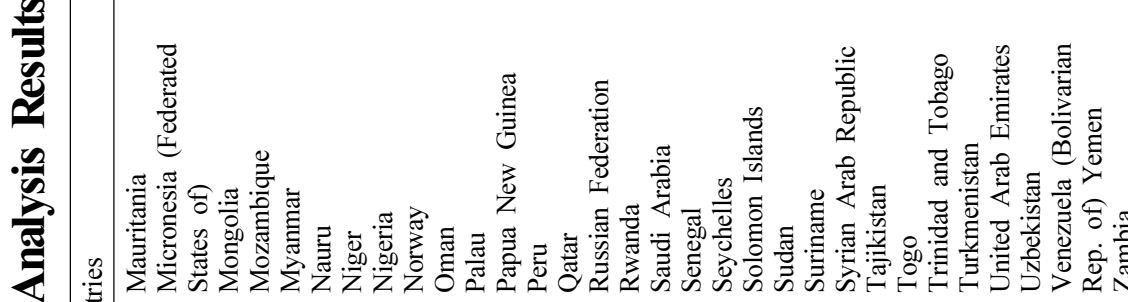

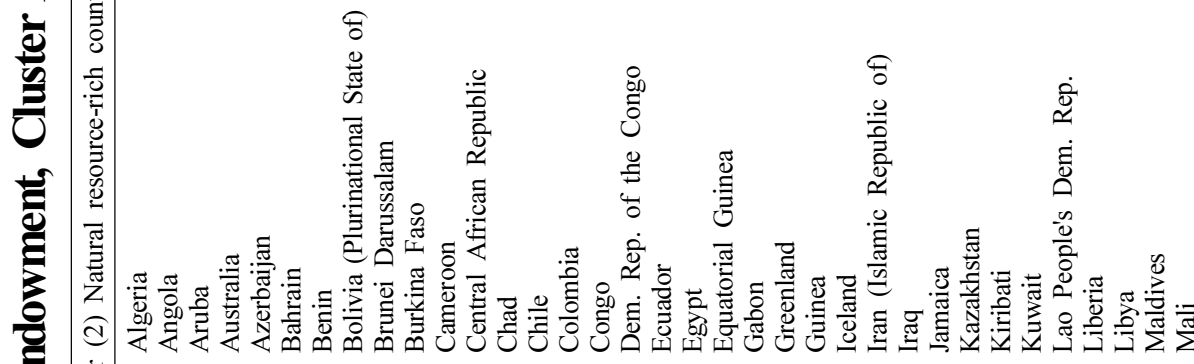

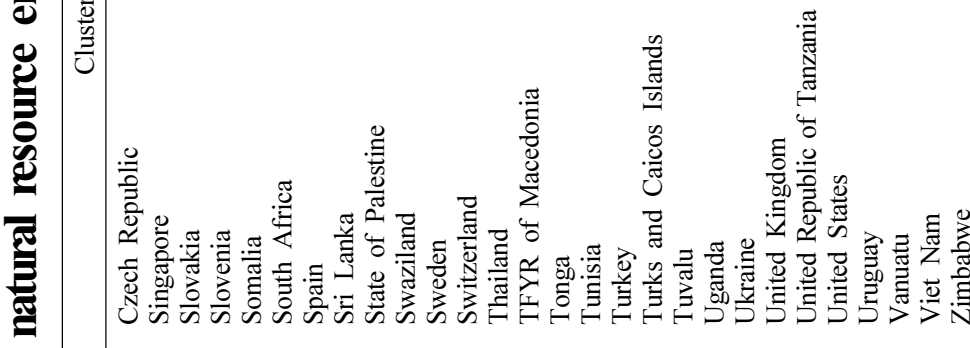

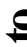

ofo

:

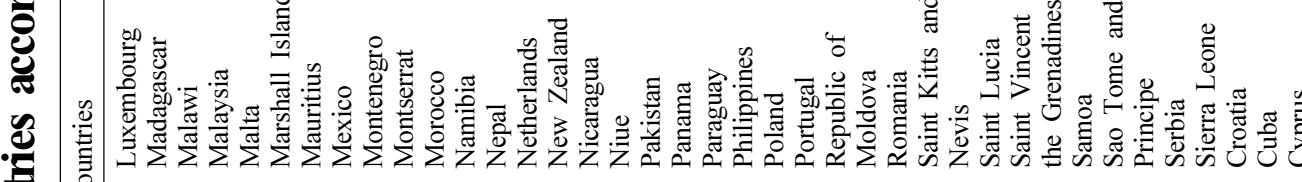




\section{Appendix 3. Adequacy of clustering}

The decision on the number of clusters is based on the analysis of variance (ANOVA). Owing to the function of this parametric technique, the number of clusters is defined in advance and the significance of the obtained solution is tested. The null hypothesis of the test is that the means between the proposed groups do not differ significantly, while the alternative hypothesis states that the means between the proposed groups differ significantly. The test is undertaken for obtaining solutions for two clusters. Since the results are statistically significant at the 5 percent level, the null hypothesis (there is no significant difference between groups) is rejected, and the solution that the analyzed countries are grouped into two clusters is accepted. The results the test are given in Appendix 3.1-at the given significance level of 5\% and at the empirical significance level of 0.000 and 0.000 , for the first and second variables, respectively, the null hypothesis is rejected. Hence, it can be concluded that the means between the two proposed clusters differ significantly.

\section{Appendix 3.1. ANOVA Analysis of clustering}

\begin{tabular}{cccccccc}
\hline & \multicolumn{2}{c}{ Classe } & \multicolumn{2}{c}{ Error } & F & Signification \\
\cline { 2 - 8 } & $\begin{array}{c}\text { Average } \\
\text { squares }\end{array}$ & ddl & $\begin{array}{c}\text { Average } \\
\text { squares }\end{array}$ & ddl & & \\
\hline Natural Resource Exports & 12,803 & 1 &, 017 & 198 & 766,729 &, 000 \\
Natural Resource Value Added Sectors & 1,076 & 1 &, 020 & 198 & 54,181 &, 000 \\
\hline
\end{tabular}

In addition, Appendix 3.2 shows the class centers that determine each cluster. For certain countries, we can see that the average share of natural resource exports in total exports of the countries is greater than 17,73, and the average share of value added of natural resources sectors in total value added is greater than 19,58; these countries are classified as natural resource-rich countries.

\section{Appendix 3.2. Class centers of clusters}

\begin{tabular}{ccc}
\hline & \multicolumn{2}{c}{ Classe } \\
\cline { 2 - 3 } & 1 & 2 \\
\hline Natural Resource Exports & 72,9794 & 17,7260 \\
Natural Resource Value Added Sectors & 35,5822 & 19,5824 \\
\hline
\end{tabular}

\footnotetext{
${ }^{1}$ Most of the countries classified as non-emerging resource-poor countries are least developed countries.
} 